\title{
An experimental investigation of differential recovery of native rodent remains from Australian palaeontological and archaeological deposits
}

\author{
Alexander Baynes ${ }^{1 *}$, Cassia J. Piper ${ }^{2,3}$ and Kailah M. Thorn ${ }^{2,4}$ \\ ${ }^{1}$ Research Associate, Department of Earth and Planetary Sciences, Western Australian Museum, \\ Locked Bag 49, Welshpool DC, Western Australia 6986, Australia. \\ 2 School of Animal Biology, The University of Western Australia, 35 Stirling Highway, Crawley, \\ Western Australia 6009, Australia. \\ ${ }^{3}$ Western Australian Museum, Locked Bag 49, Welshpool DC, Western Australia 6986, Australia. \\ ${ }^{4}$ College of Science \& Engineering, Flinders University, Bedford Park, South Australia 5042, Australia. \\ *Corresponding author: alexbaynes@iprimus.com.au
}

\begin{abstract}
Quaternary palaeontologists are often asked to identify and interpret faunal remains from archaeological excavations. It is therefore vital that both palaeontologists and archaeologists understand the limitations imposed by recovery methods, especially sieves. Fossil small mammals, particularly rodents, in Australian archaeological deposits are very significant sources of palaeoenvironmental information. Over the last half century, recovery techniques used by archaeologists in Australia have ranged from dry screening with $10 \mathrm{~mm}$ sieves to wet screening with nested sieves graded down to $1 \mathrm{~mm}$. Nested 6 and $3 \mathrm{~mm}$ sieves have been a popular combination. Experimental investigations, using owl-accumulated mammal remains from two caves, show that sieves of 2 or even $3 \mathrm{~mm}$ (the metric equivalent of 1/8th inch) are fine enough to recover most of the dissociated complete jaw bones used to identify Australian native rodents (all Muridae). But they fail to retain first molar teeth that have become dissociated from the jaws by pre-depositional fragmentation, predator digestion or damage during excavation. A $1.63 \mathrm{~mm}$ sieve (the approximate metric equivalent of $1 / 16$ th inch) differentially recovers all isolated first molars of Australian ratsized rodents, but not small mice, or some first molars of large mouse species. Our results show that differential recovery statistically significantly biases the relative abundances of rodent species retained on a sieve, although there is considerable inter-species variability. The diagonal dimension of the mesh aperture is confirmed to be at least as important as the side dimension in determining what is lost through a sieve. The demographic structure of species can also be biased by differential loss of isolated molars from the youngest individuals, but only in species whose molar dimensions precisely span the threshold of retention on a particular sieve size. Some data suggest that a greater proportion of small objects will be lost through a sieve when immersed in water, than with sprayed water wet sieving or dry screening. Because highly fragmented faunal materials are characteristic of many Australian archaeological deposits, complete recovery of isolated first molars is essential for detection and identification of rodent species to produce the comprehensive assemblages needed for valid comparisons with accumulations by single predators such as owls, and for the multivariate analyses used in palaeoenvironmental interpretations. Complete recovery of first molars of Australian rodents requires a sieve mesh aperture no larger than $1 \mathrm{~mm}$ square. A recent archaeological collection made with such methodology provides an opportunity to demonstrate that a more meticulous standard is worth the time and effort to pursue.
\end{abstract}

KEYWORDS: Differential recovery, rodents, Muridae, Australia, cave deposits, sieve size, zooarchaeology 


\section{INTRODUCTION}

A century of research on differential recovery has shown that the mesh aperture sizes of sieves used to screen sediments from excavations can fundamentally influence the type and quantity of materials recovered from them. Gifford (1916) is generally credited with being the first to consider the problem, and the first to report the mesh sizes of sieves that he used. If the smallest mesh size used is too large, remains of large fauna and flora, and large artefacts, will be recovered in the screen residues, but small remains and fine cultural materials will fall through into the screenings and be discarded. Research on differential recovery of faunal remains has been conducted mainly in North America and Europe, and has been principally concerned with vertebrate remains, particularly mammals (e.g. Ziegler 1965; Thomas 1969; Payne 1972; Shaffer 1992; Shaffer and Sanchez 1994; Lyman 2012), and fish (e.g. Gordon 1993; Nagaoka 1994, 2005; Stewart and Wigen 2003), but also invertebrates, especially molluscs (e.g. Gifford 1916; Muckle 1994). These previous investigations have demonstrated that however small a sieve mesh is used, materials of potential interest to some disciplines will be lost through it.

Experimental investigations into understanding the effects of differential recovery have generally involved one of two approaches: either applying sieves of different sizes to excavated materials from archaeological deposits, in which taphonomic factors such as fragmentation are unknown (e.g. Gordon 1993), or sieving dissociated skeletal elements of museum reference specimens which have ideal taphonomic histories (Nagaoka 2005), but lack the compounding influences on recovery of sediments and other factors (e.g. Shaffer 1992).

An early approach to the differential recovery problem involved calculation of a correction value for the differential loss of small fauna (e.g. Ziegler 1965; Thomas 1969), to boost the analyzed frequencies of the faunal material recovered with coarse sieves. But further research soon revealed that the assumptions upon which the method was based were flawed, and that losses were still seriously biasing the archaeological conclusions drawn from faunas, especially fish (e.g. Gordon 1993; James 1997; Stewart and Wigen 2003; Nagaoka 2005). Almost every investigation of differential recovery has concluded that finer sieves are desirable (e.g. Thomas 1969; Casteel 1972; Payne 1972; Shaffer 1992; Shaffer and Sanchez 1994; Lyman 2012), though the study by Vale and Gargett (2002) seems to be an exception. This, however, is balanced by the expediency of field work costs and logistics, and the much greater time required to sort fine residues (Ball and Bobrowsky 1987, but also Meighan 1969; Thomas 1969; Shaffer 1992; Nagaoka 1994; Lyman 2012). One solution is the strategy of subsampling with finer mesh (e.g. Thomas 1969; Payne 1972; Colley 1997; Stewart and Wigen 2003).
Parallel developments in quantitative analysis of Quaternary small mammal faunas (e.g. Avery 1982; Blois et al. 2010) revealed their importance for the interpretation of palaeoenvironments, including the contexts of archaeological accumulations (e.g. Morlan 1994; Stahl 1996; Veth et al. 2007; Lyman 2012).

Other principles that have emerged are that not only is there a positive correlation between the size of the mesh aperture, the size of the animal and the probability of its remains being retained on the sieve (e.g. Thomas 1969; Casteel 1972; Shaffer 1992; Lyman 2012), but that the shape of the specimens, particularly bones desired for identification, is also very important (e.g. Shaffer 1992; Nagaoka 2005; Lyman 2012). If the two smallest dimensions of an object are smaller than the side of the mesh (Nagaoka 2005), or the diagonal of the aperture (Lyman 2012), it can potentially fall through. The evenness of the three dimensions of roughly cubic or spheric objects, such as upper molar teeth of mammals, means that they are more likely to be retained than rod-shaped objects such as long bones. Disc- or kite-shaped objects with two large and one small dimension also tend to be retained.

It is important to investigate whether Australian mammals have skeletal characteristics that make them susceptible to biases from particular recovery methods that differ from those shown by faunas elsewhere. While differential recovery of fish remains has been investigated in Australia (Vale and Gargett 2002; Gargett and Vale 2005), mammals have not been similarly considered. As faunas differ between continents, differences in skeletal morphology may cause different recovery biases. For example, Australian native rodents are all Muridae, which have molar teeth with roots that close shortly after eruption and are often not vertically aligned with the crown, but angle away from it. Whereas voles, which are abundant components of many Northern Hemisphere faunas, but absent from Australia, often have cheek teeth with short straight roots that remain open throughout life, which may give their molars different retention properties on sieves from those of murids. Furthermore, Australian native non-volant carnivores (not considered in this study) are all marsupials, unlike faunas elsewhere.

Equally significantly, there are faunal remains in many collections of screen residues from archaeological excavations made in Australia during the 20th century, generally using relatively coarse sieve sizes, that remain to be investigated. It is vital to understand the quantitative limits of such samples. An example of how sieve size can affect interpretation of Australian fossil faunas is provided by Caladenia Cave, in which the sieve size used in a 1970s excavation was changed from $3 \mathrm{~mm}$ to $1 \mathrm{~mm}$ for the lowest third of the deposit (Thorn et al. 2017, p. 218). In a multivariate analysis of the 
relative abundances of small mammals from the site, this change of sieve mesh size proved to be the overwhelming factor, obscuring any ecological signal in the data. Similar limitations apply to reanalysis of old collections elsewhere in the world (e.g. Nagaoka 2005). It is therefore important to bring differential recovery to the attention of Australian archaeologists and palaeontologists, to highlight the fact that it can have just as much influence on Australian environmental and ecological reconstructions, on which archaeological interpretations are in turn based, as those overseas.

Remains of small vertebrates, especially small mammals, are often abundant in Australian cave deposits (e.g. McDowell 2014), both those with and without a major archaeological component. Across the drier parts of Australia, which cover much of the continent, the principal accumulator of mammal bones is the Australian Barn Owl, Tyto delicatula. Typical of owl accumulations, the skeletal elements are largely dissociated. The small mammals, particularly the murid rodents, in Australian archaeological deposits are very significant sources of palaeoenvironmental information (e.g. Balme et al. 1978; Veth et al. 2007). Because both relative abundance and presence-absence data are important, differential loss of remains as a consequence of the size of a species not only biases results, but invalidates comparisons with faunas from bulk samples from non-archaeological assemblages (providing that these in turn have been recovered using a fine enough mesh size).

Quaternary palaeontologists, particularly those specializing in vertebrates, are frequently asked by archaeologists to identify and interpret faunal remains from their excavations, so it is vital that both groups understand the limitations imposed by recovery methods, especially sieves. We therefore devised experimental investigations of the effects of sieve size upon recovery of remains of Australian native rodents from two cave deposits, one purely palaeontological (with no apparent human input) and one predominantly palaeontological but with a minor archaeological component (i.e. some human input). The results from these are compared with a quantified rodent fauna from a recent excavation in a predominantly archaeological site. From this we derive an answer to the question of what sieve mesh size is required to fully recover identifiable remains of Australian native rodents. We also investigated whether differential recovery can bias the demographic structure of remains of species retained on a sieve. We then review how adequately recent archaeological excavations in Australia have sampled faunal material, and suggest a new standard of investigation that would enable palaeontologists to make more detailed and accurate interpretations of zooarchaeological materials provided to them.

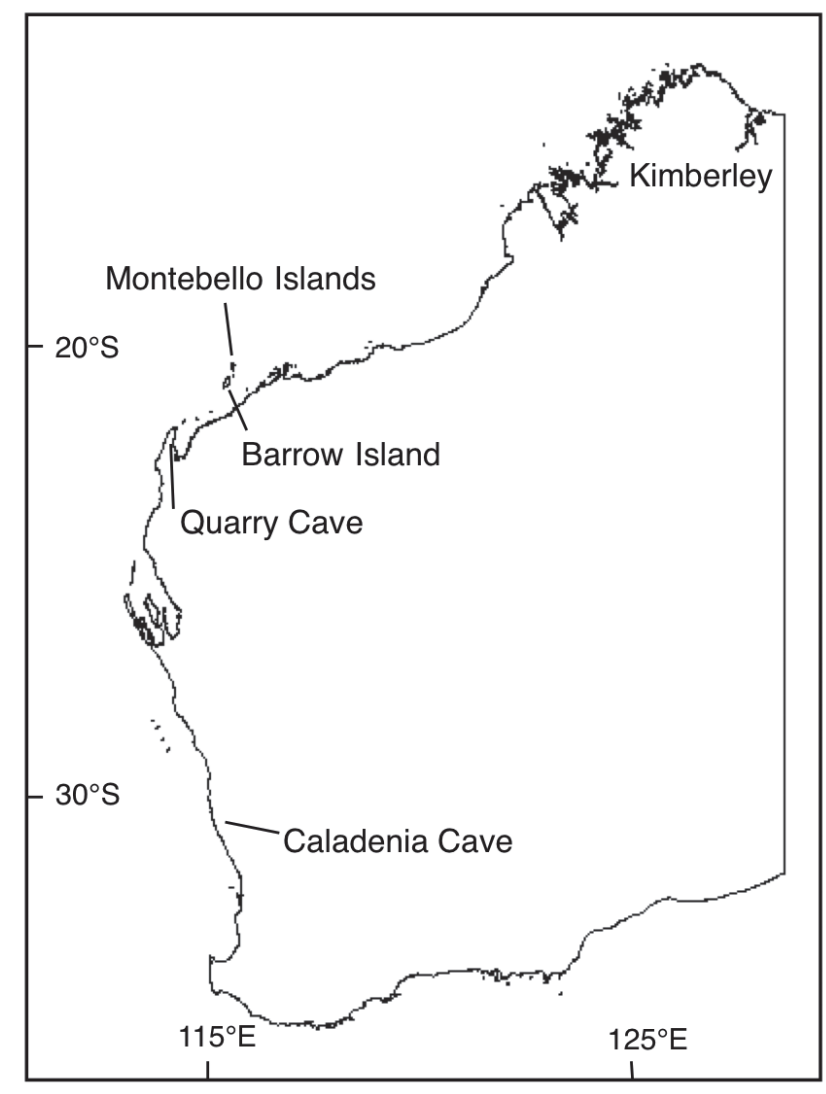

FIGURE 1 Map of Western Australia showing localities mentioned in the text.

\section{MATERIALS AND METHODS}

\section{CAVE SITES}

The majority of experimental materials used in this investigation were sourced from two caves, Quarry Cave (C-599) at $21^{\circ} 59^{\prime} 49^{\prime \prime} \mathrm{S}, 114^{\circ} 05^{\prime} 45^{\prime \prime} \mathrm{E}$ in the eastern stony footslopes of Cape Range in north-western Australia, and Caladenia Cave (EM-17) at $31^{\circ} 14^{\prime} 49^{\prime \prime} \mathrm{S}, 15^{\circ} 37^{\prime} 39^{\prime \prime} \mathrm{E}$ on the northern Swan Coastal Plain in south-western Australia (Figure 1), with an additional small sample from Boodie Cave on Barrow Island.

Quarry Cave was discovered in 1996 in the course of quarrying operations in Miocene marine limestone. It is a pot hole consisting of a single chamber, roughly triangular in plan, with a fairly even rocky floor that slopes gently downwards from the apex of the triangle to a small area of sediments at the base of the triangle. Maximum dimensions of the floor are about $19 \mathrm{~m}$ long by $17 \mathrm{~m}$ wide. When discovered, the only entrance to the cave was in a steep rock face and consisted of a low horizontal slot, about $1.3 \mathrm{~m}$ wide and $0.7 \mathrm{~m}$ high, beneath a cap rock, that opened into a small ceiling dome above the deepest part of the cave, some $6 \mathrm{~m}$ above the floor, with all walls overhung beyond vertical. This restricted the cave's suitability as a shelter for animals to those that could fly or climb well; and excluded larger mammals such as kangaroos or humans without modern climbing equipment. Bones, mainly of small mammals, 
and probably owl-accumulated, were quite abundant on the floor and in the shallow sediments. They are mostly brown in colour and moderately fragile, but generally fairly anatomically complete. The bones have not been dated, but the geomorphology of the cave suggests that its small entrance opened relatively recently, and the bones probably only began to accumulate in the late Holocene. At the time of discovery it seemed likely that the cave would be destroyed in the course of the quarrying operations, so bones were collected by shoveling bulk samples of the sediment into four sacks, each holding about $5 \mathrm{~kg}$. The contents of one of those sacks provided materials used in this study.

Caladenia Cave is located in a shallow valley at the base of a hill slope composed of Pleistocene aeolian limestone. It is an inclined fissure cave (Bastian 1964) consisting of a single chamber about $16 \mathrm{~m}$ long and $9 \mathrm{~m}$ wide, with low lateral extensions, described in more detail in Thorn et al. (2017). Block collapse at the northern end of the chamber has formed a small walkin entrance. Outside it there is a roughly semicircular doline of about $5 \mathrm{~m}$ radius. Ceiling height along the midline of the chamber is generally a little over $2 \mathrm{~m}$, but a major collapse near the southern end of the chamber has produced a chimney, an opening in the roof, and a substantial rock pile beneath. A large volume of sandy sediments, and plant débris, has flowed in from the northern entrance and formed a floor that slopes to the south. A $3.6 \times 1.2 \mathrm{~m}$ excavation was made in the $1970 \mathrm{~s}$ near the middle of the floor between the rock pile and the western wall. Sediments from the upper two-thirds of the deposit were screened using a sieve with a mesh aperture of $3 \mathrm{~mm}$, but because bone was more fragile and fragmented in the lowest third of the deposit the sieve size was changed to $1 \mathrm{~mm}$.

\section{AUSTRALIAN RODENT SKULL MORPHOLOGY}

Rodents are the most abundant component of the fossil assemblages from both caves. All are typical Muridae (see, for example, Cook 1965); and have just one incisor and three molars in each left and right upper and lower dentition. The upper molars are rooted in alveoli in a roughly horizontal bone plate towards the posterior end of the maxilla. Anterior to the molars a zygomatic plate rises to, and then curves laterally and posteriorly into, the proximal portion of the zygomatic arch (Figure 2). Anterior to the maxilla is the premaxilla, which holds the upper incisor. There is a substantial diastema between the incisor and first molar. The lower jaw, composed of the dentary bone, is typical of placental herbivores in having a long low diastema behind the incisor, with the molar row in the centre of the jaw, and fairly flat processes for articulation and muscle attachment projecting above and below the occlusal plane at the posterior end of the jaw. The length and height of the lower jaw are its main dimensions and are much greater than its width.

\section{CHARACTERS USED IN AUSTRALIAN MURID SKULL IDENTIFICATION}

Australian murid skeletal remains are identified using mainly characters of the upper and lower jaws and teeth. For the upper jaw, the shape of the zygomatic plate and zygomatic arch, the length and shape of the anterior palatine foramen, and the cross-sectional shape and relative size of the incisor, if the premaxilla is still attached, are particularly important. In the lower jaw, the shape and position of the ascending ramus and coronoid process, the shape of the angular process, the position of the masseteric ridge and its relationship to the mental foramen, and the cross-sectional shape and relative size of the incisor are all taxonomically diagnostic characters.
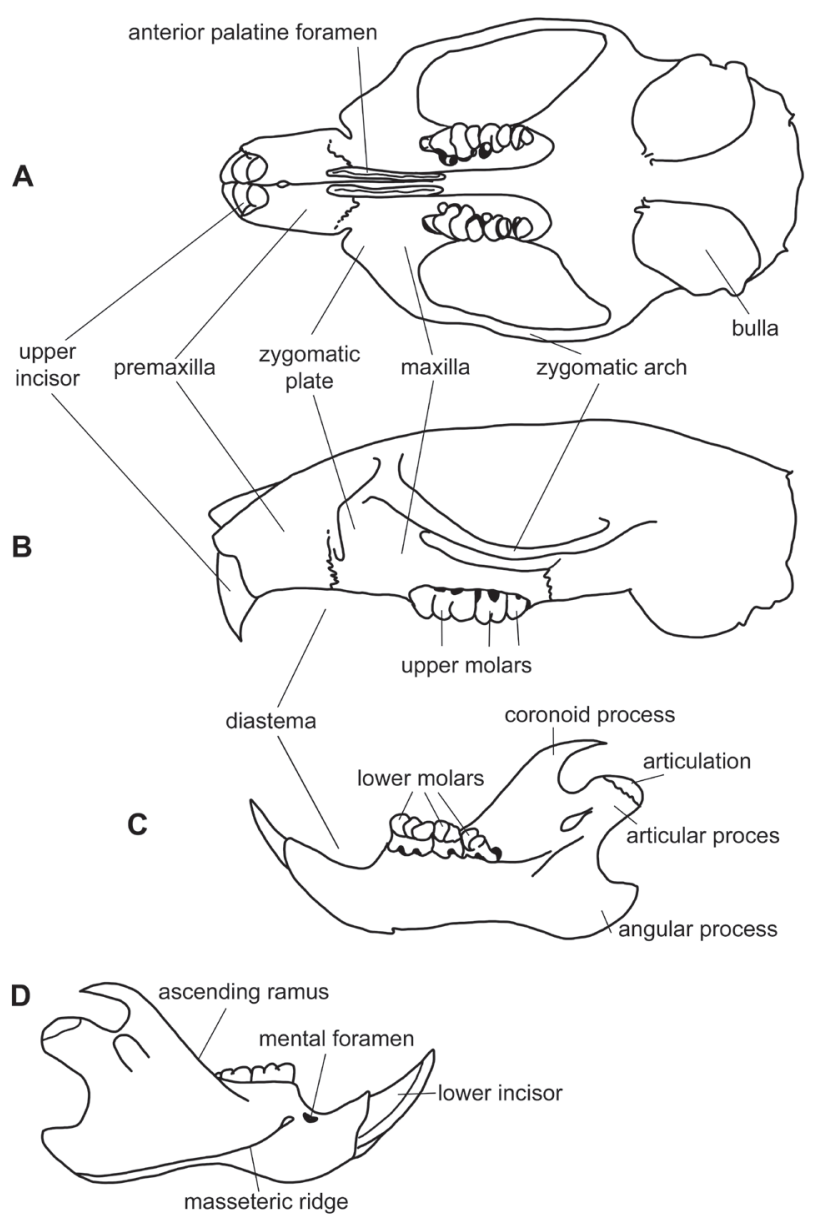

FIGURE 2 Sketch diagram of a murid rodent skull (based on Rattus tunneyi), illustrating the teeth, bones and morphological structures whose character states can be diagnostic for species (see text). A, Occlusal (palate) view of skull. B, Left lateral view of skull. C, Medial (internal or lingual) view of right lower jaw (dentary bone). D, Lateral (buccal) view of right lower jaw. 


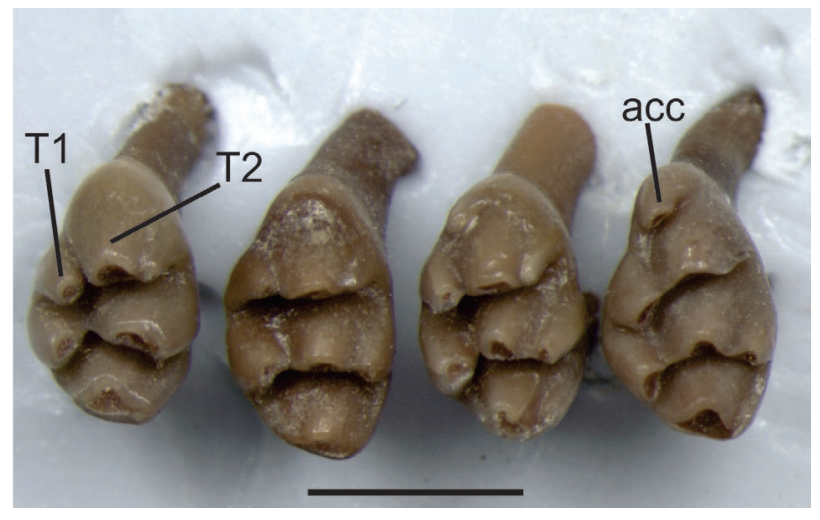

FIGURE 3 Photograph of the left first upper molar teeth, in occlusal view, of the four large mice from Quarry Cave (the four species in the fauna with the most similar molars); from left to right, Notomys alexis, Pseudomys desertor, $P$. fieldi and $P$. nanus. The species can be distinguished from each other on the basis of the relative size and shape of cusp $\mathrm{T} 1$, and its position relative to cusp T2, and the development of the anterior cingular cusp (acc). The scale bar is $2 \mathrm{~mm}$.

Morphological characters of the molar teeth of Australian murids are also employed in their identification. The crowns of the molars cease growing as they erupt. First molars, both upper and lower, are the largest and most complex, and the teeth diminish in size and complexity posteriorly. Third molars are generally relatively small. First molars, even when isolated from jaws, can usually be identified to species, but few second molars and virtually no third molars can. The most important characters are the presence, size and shape of cusps, and their relationships with other cusps (see, for example, Figure 3), and the number and patterns of roots. The crowns of upper first molars are generally ovoid in shape, with the blunt end at the rear, adjacent to the second molar. The roots consist of one large root angled forwards and laterally as well as upwards at the anterior end of the tooth, with, in most Australian genera, a single vertical root in the centre of the inner, lingual, side of the tooth, and a third root on the posterior outer, buccal, corner. In the genus Rattus there are two lingual roots and an additional small buccal root between the anterior and posterior roots (see Figure 4). Additional small roots are variably developed, particularly in the largest species. Lower first molars are roughly rectangular in occlusal view. There is a stout vertical root at each end of the tooth, and small additional roots may be variably developed between them, particularly on the lingual side. In the genus Rattus one small central root is present on both sides of the molar. In a complete first lower molar tooth the length of the crown and the depth to the end of the roots are the two largest dimensions. Second molars are roughly round (upper) or square (lower) in occlusal view, and third molars are typically triangular.
In murid material from owl accumulations, including many in Australia, the crowns and roots of some molar teeth are incompletely formed, suggesting that the animals were very young when predated. After digestion by owls, the molars of the youngest animals typically consist of no more than the thin and fragile enamel shell of the crown, and completely lack roots (Andrews 1990; Fernández-Jalvo et al. 2014). With increasing age, dentine thickens and strengthens the crowns, and the roots are developed by use. This process appears to continue throughout the life of the animal because some of the most robust roots are found on molars with extremely worn crowns.

\section{TAPHONOMY: MURID JAW FRAGMENTATION}

Fragmentation of faunal remains in Quaternary fossil assemblages is a normal state. Typically, it is most severe in archaeological accumulations (e.g. Shaffer 1992; Muckle 1994), due mainly to human food extraction techniques and trampling. Fragmentation of murid jaws shows consistent patterns. Predictably, the thin sheets of bone that form the anterior part of the zygomatic plate of the maxilla and the ascending ramus and angular process of the dentary (see Figure 2) are the most vulnerable, with damage proceeding from chipped edges to complete loss. As fragmentation becomes more severe, progressively thicker bone is broken off until only the most robust parts of the jaws remain. In both upper and lower jaws, these consist of the thick bone that surrounds the first molars and their alveoli, and without the molars few if any characters for identification are left beyond size and number and disposition of roots. Because the relatively thick bone that surrounds the long lower incisor in the dentary extends through much of the length of the bone, dentaries tend to be less fragmented than maxillae.

Fragmentation of the jaw bones is not the only reason why molars become isolated. Digestion by predators, particularly owls, usually dissolves the ligaments attaching the molar roots into their alveoli. If the roots are close to parallel, rather than widely splayed, or are short, or poorly developed, as in a young animal, the teeth may be dissociated from the jaws before even being voided by the predator. Root structure is usually consistent within species and so some are especially susceptible to loss of molars from jaws. For example, the three roots of the first upper molar of Western Mouse (Pseudomys occidentalis, a member of the Caladenia Cave fossil fauna) are shorter and less splayed than those of most species, so the vast majority of maxillae of $P$. occidentalis from owl accumulations lack a first molar.

\section{EXPERIMENTAL METHODS}

Dry bulk material from one sack of sediment from Quarry Cave (about $5 \mathrm{~kg}$ in weight), was gently washed with water flowing from a $12 \mathrm{~mm}$ (half inch) garden hose 
through a $3 \mathrm{~mm}$ square mesh aperture archaeological sieve, and the screenings collected on a $0.5 \mathrm{~mm}$ square mesh sieve. After drying, the screenings were gently dry-sieved on $1.63 \mathrm{~mm}$ and $0.71 \mathrm{~mm}$ square laboratory sieves to obtain three screen residue fractions each with fairly even particle size, for more efficient sorting (cf. Wolff 1975). Sieves of those two mesh sizes were used because they happened to be available, but the $1.63 \mathrm{~mm}$ sieve has an only slightly larger mesh aperture than a 1/16th inch $(1.59 \mathrm{~mm})$ sieve. Mammal jaws and isolated teeth were sorted from the three fractions, and the rodents identified. Rodent jaw bones and jaw fragments containing first molars, and isolated rodent first molars, were counted.

For Caladenia Cave, previously identified remains of each rodent species from a single excavation spit collected at $1.79-1.81 \mathrm{~m}$ depth, and originally screened with the $1 \mathrm{~mm}$ sieve, were tipped onto the same $3 \mathrm{~mm}$ archaeological sieve and gently brushed across its surface, until no more specimens fell through. The numbers that had been retained and fallen through were then counted.

Jaw specimens with first molars, and isolated first molars, from both sites, were originally counted in five categories of completeness ranging from essentially intact jaws, with all three molars in place (category 1), through three stages of loss of other molars and bone fragmentation (2-4), to isolated molars (5). The data are recorded in Appendix Tables A2 and A7 in the five categories (defined in Appendix Table A1), but categories 2-4 are combined as molars in jaw fragments for plotting in Figures 5-7 and 17.

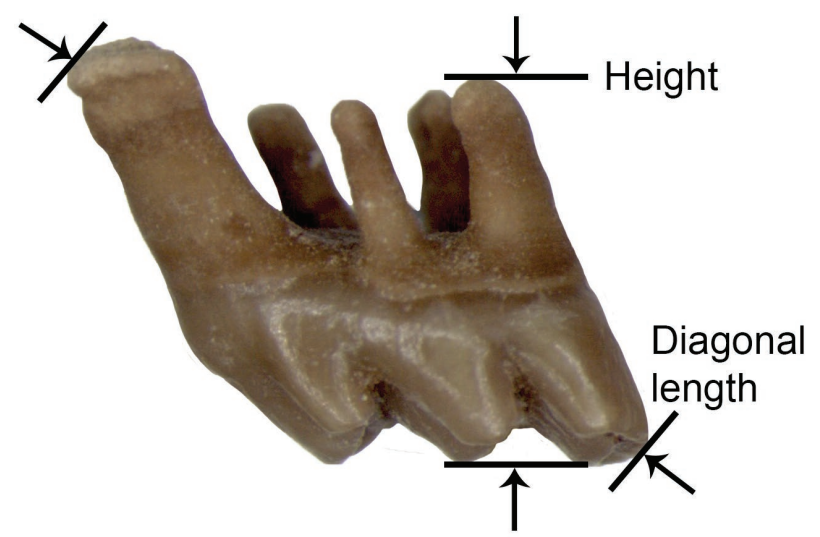

FIGURE 4 Isolated left first upper molar of Rattus tunneyi from Quarry Cave, in life position, with roots uppermost and crown below, showing positions of height and diagonal length measurements. The tooth is from an age class 2 individual with fully developed roots with closed tips and moderate wear on the cusps, and is viewed from the outer (buccal) side.
First molars of two species at the threshold of retention on the $3 \mathrm{~mm}$ sieve provided the opportunity to investigate in detail why some isolated teeth were retained whereas others fell through and were lost, and also whether differential recovery can bias the demographic structure of the specimens retained on the $3 \mathrm{~mm}$ sieve. In addition to the standard measurements of crown length and width, the height of the tooth from the top of the cusps to the tip of the roots, or broken remnants thereof, and the greatest diagonal length of the tooth were measured, to the nearest $0.02 \mathrm{~mm}$, using Vernier calipers, as shown in Figure 4. The teeth were also assigned to one of five age classes, ranging from 1 , youngest, to 5, oldest, based on root development and cusp wear (see Appendix Table A4).

An almost ideal empirical test of the experimental results has been provided by data from an excavation made in 2013 in Boodie Cave on Barrow Island (Veth et al. 2014), in which wet screening with nested 4, 2 and $1 \mathrm{~mm}$ sieves was used.

\section{RESULTS}

\section{QUARRY CAVE RODENT FAUNA}

The fauna recovered from the Quarry Cave sample includes 12 species of rodents, consisting of three species of small mice (mean adult body weights 12-17 g), Pseudomys hermannsburgensis (Sandy Inland Mouse), Pseudomys chapmani (Pebble-mound Mouse) and Leggadina sp. cf. L. lakedownensis (cf. Lakeland Downs Mouse), four large mice (25-40 g), Notomys alexis (Spinifex Hopping-mouse), Pseudomys desertor (Desert Mouse), Pseudomys fieldi (Shark Bay Mouse) and Pseudomys nanus (Western Chestnut Mouse), three rat-sized species (80-120 g), Rattus tunneyi (Pale Fieldrat), Notomys longicaudatus (Long-tailed Hoppingmouse) and Zyzomys pedunculatus (Central Rock-rat), one large rat (210 g), Leporillus conditor (Greater Stick-nest Rat), and one squirrel-sized tree-rat (310 g), Mesembriomys macrurus (Golden-backed Tree-rat). Isolated first molars, both upper and lower, of all 12 can be distinguished at the species level.

The raw count data for the Quarry Cave rodents from the various sieve fractions (Appendix Table A2) are plotted in Figures 5-7, and reflect the variable abundances of the species in the deposit. With total numbers of specimens per species varying between 427 and 3, relative abundances, the alternative to the absolute abundances used, would distort the representations of the rarest species and obscure the ecological information contained in the proportions of the species in the death assemblage. In Figures 5 and 6 the numbers of specimens lost through the $3 \mathrm{~mm}$ sieve are the sums of those retained by the two smaller sieves listed in Table A2. The species are arranged across the graphs in order of upper first molar crown 
size from smallest on the left to largest on the right. The smallest species, Pseudomys hermannsburgensis, is the most abundant, which is typical of owl accumulated assemblages from the drier parts of Australia. As would be expected, the numbers of jaws retained on the $3 \mathrm{~mm}$ sieve (Figure 5) increase with the size of the species and completeness of the specimens, which varies from essentially intact jaws (black filled columns) to bone fragments retaining the first molar (grey filled columns). All five species of Pseudomys (abbreviated ' $P$ ') show a similar pattern of loss of the vast majority of their isolated molars (white filled columns) through the $3 \mathrm{~mm}$ sieve. The Leggadina (' $L g$ ') differs in having a relatively lower number of isolated molars, but most of these were also lost through the sieve. A slightly higher proportion of isolated molars of Notomys alexis (' $N a$ ') was retained than for the three comparably sized species of Pseudomys (see also Figure 3), plotted to the right of it. But substantial proportions of isolated molars of the three rat-sized species $(R t, N l$ and $Z p)$ were also not retained. Most remarkably of all, one specimen of the largest rodent molar in the entire assemblage, a first lower molar of the tree-rat $(M m)$, also fell through. That particular specimen completely lacks roots, otherwise it would almost certainly have been retained on the $3 \mathrm{~mm}$ sieve.

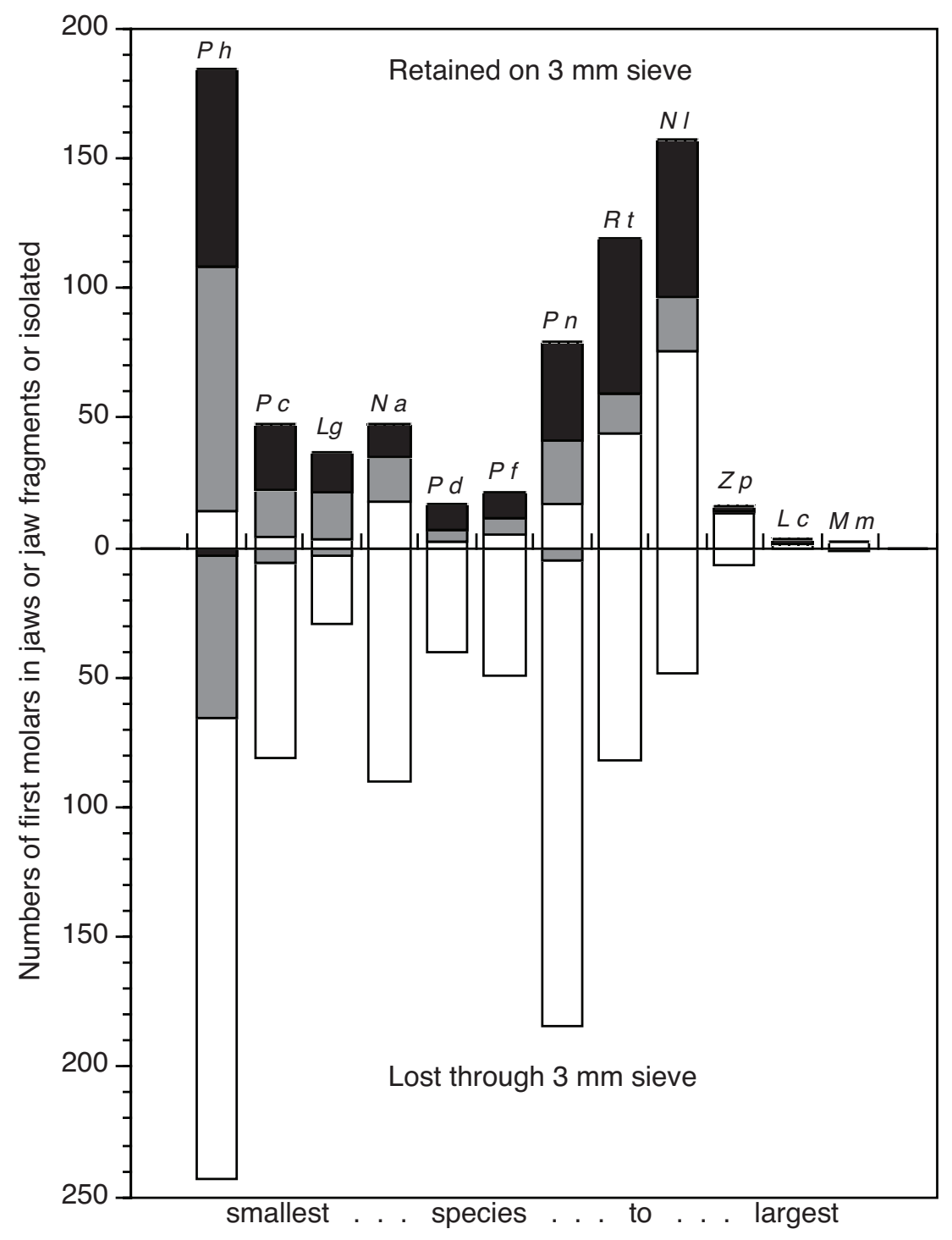

FIGURE 5 Combined numbers of upper and lower first molar teeth in complete jaws (black fill), in jaw bone fragments (grey fill) or isolated first molars (white fill), retained by (above the horizontal line) or lost through (below the line) a $3 \mathrm{~mm}$ sieve, represented by the horizontal line across the middle of the figure, from 12 rodent species from Quarry Cave, arranged by size of first upper molar from smallest on the left to largest on the right. The species are, left to right: Pseudomys hermannsburgensis ( $P$ h), Pseudomys chapmani (P C), Leggadina sp. cf. L. lakedownensis ( $L g)$, Notomys alexis ( $N$ a), Pseudomys desertor $(P d)$, Pseudomys fieldi ( $P$ f), Pseudomys nanus ( $P$ n), Rattus tunneyi $(R$ t), Notomys longicaudatus (N I), Zyzomys pedunculatus ( $Z$ p), Leporillus conditor ( $L \mathrm{c}$ ), and Mesembriomys macrurus ( $\mathrm{M}$ ). 


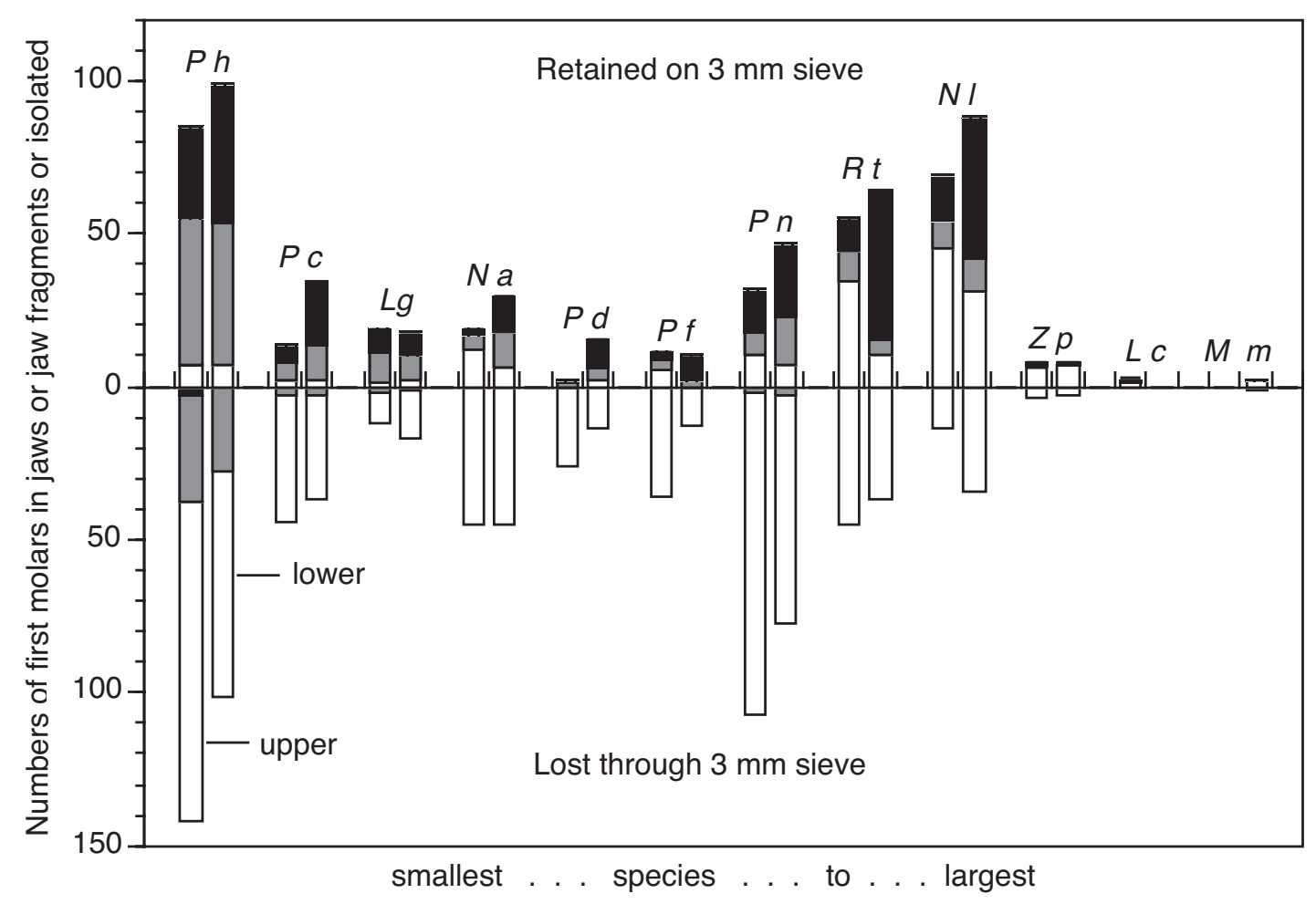

FIGURE 6 Separate numbers of upper (left column in each pair) and lower (right column) first molar teeth in complete jaws (black fill), in jaw bone fragments (grey fill) or isolated first molars (white fill), retained by (above the horizontal line) or lost through (below the line) a $3 \mathrm{~mm}$ sieve, represented by the horizontal line across the middle of the figure, from 12 rodent species from Quarry Cave, arranged by size of first upper molar from smallest on the left to largest on the right. The species are, left to right: Pseudomys hermannsburgensis ( $P$ h), Pseudomys chapmani (P C), Leggadina sp. cf. L. lakedownensis (Lg), Notomys alexis (N a), Pseudomys desertor ( $P$ d), Pseudomys fieldi ( $P$ f), Pseudomys nanus $(P n)$, Rattus tunneyi $(R t)$, Notomys longicaudatus $(N$ I), Zyzomys pedunculatus ( $Z$ p), Leporillus conditor ( $L C$ ), and Mesembriomys macrurus ( $M$ m).

When both retained and lost specimens are considered together, the fragmented jaws (grey fill) only make up a substantial proportion of the three smallest species, particularly Pseudomys hermannsburgensis. Moving up the species size scale, the specimens consist more and more of either essentially complete jaws or isolated molars. This pattern presumably arises because the jaws of the smallest species are the most fragile and those of larger species are more robust and resistant to causes of fragmentation.

In Figure 6, the same count data as used in Figure 5 are separated into upper and lower jaws and molars. This plot shows a general pattern in most of the abundant species of less fragmentation of lower jaws (longer black-filled columns) and greater retention of lower molars in bone, resulting in better retention of lowers than uppers by the $3 \mathrm{~mm}$ sieve (columns above the horizontal line). The five species of Pseudomys, Rattus tunneyi and Zyzomys pedunculatus are consistent with this pattern in showing greater numbers of isolated upper than lower molars, most of which are not retained (white-filled columns below the line). The Leggadina ( $L g$ ) and Notomys longicaudatus, show the opposite pattern, with more isolated lower molars not retained. Although Notomys alexis shows more isolated upper molars than lowers, the numbers not retained are equal.

Both Figures show that the isolated molars of the three rat-sized species ( $R t, N l$ and $Z p$ ) lie at the threshold of retention on a $3 \mathrm{~mm}$ sieve. This pattern is analyzed in detail in a separate section below.

The specimens not retained by the $3 \mathrm{~mm}$ sieve were then screened on a $1.63 \mathrm{~mm}$ sieve, and the results are shown in Figure 7. Almost all specimens that included any bone attached to the first molars were retained on the $1.63 \mathrm{~mm}$ sieve. But not only did most of the isolated molars of the three small mice fall through the 1.63 $\mathrm{mm}$ mesh (as well as the $3 \mathrm{~mm}$ ), so did a few of those of the large mice. All isolated first molars of rat-sized and larger species were retained by the $1.63 \mathrm{~mm}$ sieve.

\section{EFFECTS OF DIFFERENTIAL RECOVERY ON RODENT NISP FROM QUARRY CAVE}

The results of the sieving experiments with $3 \mathrm{~mm}$ and $1.63 \mathrm{~mm}$ sieves, above, raise the question of what effect the differential recovery would have upon any NISP 


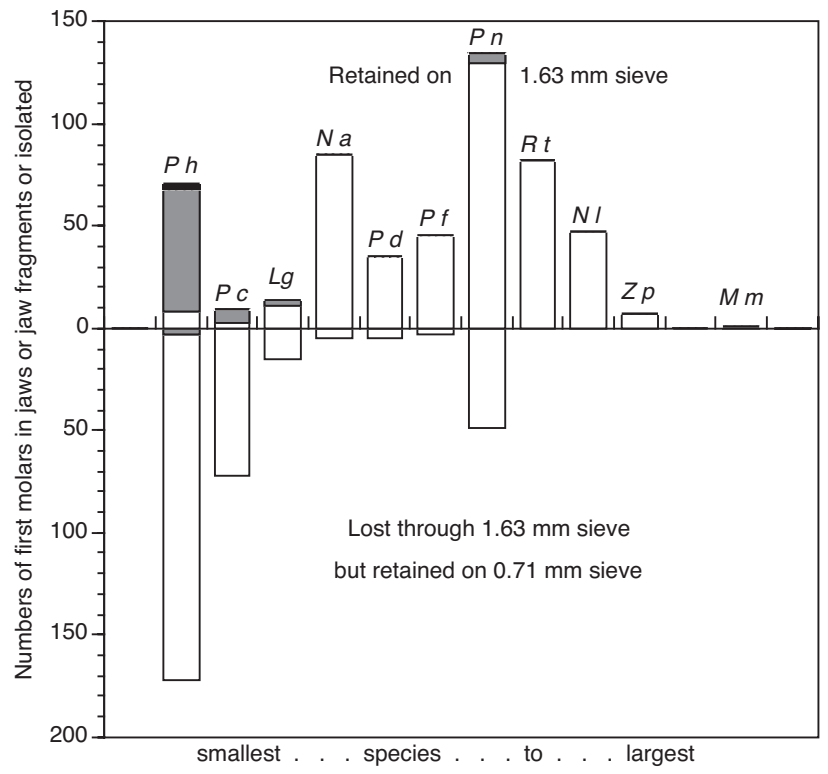

FIGURE 7 Combined numbers of upper and lower first molar teeth in complete jaws (black fill), in jaw bone fragments (grey fill) or isolated first molars (white fill), retained by (above the horizontal line) or lost through (below the line) a $1.63 \mathrm{~mm}$ sieve, represented by the horizontal line across the middle of the figure, from 11 rodent species from Quarry Cave, arranged by size of first upper molar from smallest on the left to largest on the right. The species are, left to right: Pseudomys hermannsburgensis ( $P$ h), Pseudomys chapmani (PC), Leggadinasp. cf. L. lakedownensis $(\mathrm{Lg})$, Notomys alexis $(\mathrm{N}$ a), Pseudomys desertor ( $P$ d), Pseudomys fieldi $(P f)$, Pseudomys nanus ( $P$ n), Rattus tunneyi $(R t)$, Notomys longicaudatus (N I), Zyzomys pedunculatus $(Z \mathrm{p})$, and Mesembriomys macrurus $(\mathrm{M} \mathrm{m})$. [number of identified specimens] or MNI [minimum number of individuals] figures generated from those sieve residues for the Quarry Cave rodent species. Percentages of total NISP of each of the 12 species retained in the three sieve fractions are given in Table 1. Percentages, rather than raw count figures, are used to enable comparisons to be made between the species present in different abundances. Percentage values for the nine most abundant (and smallest) species in the two larger sieve fractions are plotted in Figure 8 (overleaf). (The sample sizes for the three largest species are too small for the data to be meaningful.) Figure 8 also summarises much of the content of Figures 5-7.

With one exception, the percentage figures for the $3 \mathrm{~mm}$ sieve show a surprising uniformity through both the small and medium-sized mice of about $1 / 3$ of NISP retained, i.e. about $2 / 3$ lost through that sieve. Specimens of these six species constitute about $68 \%$ of the total NISP from the bulk sample (1084 of 1585). The combined values for the 1.63 and $3 \mathrm{~mm}$ sieves plotted in Figure 8 are intended to simulate the effect of sieving the whole sample of bulk material with just a $1.63 \mathrm{~mm}$ sieve, and are contingent upon the assumption that all specimens retained by the $3 \mathrm{~mm}$ sieve would also have been retained by the $1.63 \mathrm{~mm}$ sieve if used alone. While there is a general trend to greater retention of larger species, with the two rat-sized species reaching $100 \%$ retention by the $1.63 \mathrm{~mm}$ sieve, inter-species variation in retention is still large even on the finer sieve.

The relative abundance figures (Table 2, overleaf) for both sieve fractions, but particularly the $3 \mathrm{~mm}$, show closed array effects. For example, the relative abundance of Notomys longicaudatus in the $3 \mathrm{~mm}$ is approaching twice that in the whole sample, probably

TABLE 1 Percent figures (rounded to two places of decimals) of total NISP for each Quarry Cave rodent species retained in each of the three sieve fractions. Species are listed by size of first upper molar from smallest at the top to largest at the bottom.

\begin{tabular}{|c|c|c|c|}
\hline Species & $3 \mathrm{~mm}$ sieve & $1.63 \mathrm{~mm}$ sieve & $0.71 \mathrm{~mm}$ sieve \\
\hline Pseudomys hermannsburgensis & 43.09 & 16.63 & 40.28 \\
\hline Pseudomys chapmani & 37.21 & 6.98 & 55.81 \\
\hline Leggadina sp. cf. L. lakedownensis & 56.06 & 21.21 & 22.73 \\
\hline Notomys alexis & 34.78 & 61.59 & 3.62 \\
\hline Pseudomys desertor & 29.82 & 61.40 & 8.77 \\
\hline Pseudomys fieldi & 30.00 & 65.71 & 4.29 \\
\hline Pseudomys nanus & 30.04 & 51.33 & 18.63 \\
\hline Rattus tunneyi & 59.20 & 40.80 & 0.00 \\
\hline Notomys longicaudatus & 76.59 & 23.41 & 0.00 \\
\hline Zyzomys pedunculatus & 69.57 & 30.43 & 0.00 \\
\hline Leporillus conditor & 100.00 & 0.00 & 0.00 \\
\hline Mesembriomys macrurus & 66.67 & 33.33 & 0.00 \\
\hline
\end{tabular}




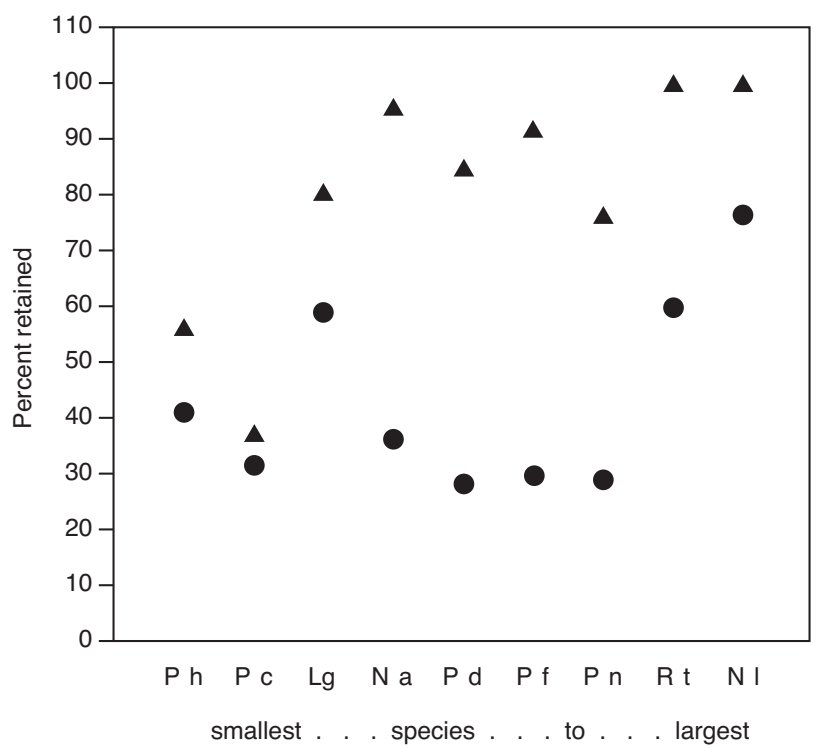

FIGURE 8 Percent of total NISP for the nine most abundant (and smallest) rodents in the Quarry Cave assemblage retained on the $3 \mathrm{~mm}$ sieve alone (filled black circles) and on the $3 \mathrm{~mm}+1.63 \mathrm{~mm}$ sieves (filled black triangles). Species arranged by size of first upper molar from smallest on the left to largest on the right. The species are, left to right: Pseudomys hermannsburgensis ( $P$ h), Pseudomys chapmani (P C), Leggadina $\mathrm{sp}$. cf. L. lakedownensis ( $\mathrm{Lg})$, Notomys alexis ( $N$ a), Pseudomys desertor $(P d)$, Pseudomys fieldi ( $P$ f), Pseudomys nanus $(P n)$, Rattus tunneyi $(R$ t) and Notomys longicaudatus (N I). because differential recovery has reduced the numbers of specimens of the smaller species and artificially raised the proportions of the better-retained abundant larger species. But, again, this view of the data highlights variability in retention between the species as the most important factor affecting their relative abundances in the two sieve fractions. This is probably because the differences in morphology of the species, even though minor, have a major effect upon their differential retention in sieves. To test whether the sieving had statistically significantly biased the relative abundances, the null hypothesis used was that the two sieves retain the species in the same proportions as they occur in the whole sample. The very high $X^{2}$ values (Table 2; for calculations see Appendix Table A3) indicate that the results are highly statistically significantly different from expected, when compared with critical values of the chi-square distribution, and the null hypothesis is rejected. Clearly the relative abundances have been biased by the sieving.

Both zooarchaeologists and palaeontologists routinely calculate diversity indices for fossil faunal assemblages with large sample sizes, to investigate the species richness, evenness and heterogeneity of the prey samples, and the dietary breadth of the accumulating predators, particularly when these include humans. Indices were calculated for the Quarry Cave rodent data for the whole sample and two sieve fractions listed in Table 2, to determine whether the indices have been biased by the sieving. We used formulae from May (1975), but

TABLE 2 NISP and relative abundances (\%NISP rounded to 2 places of decimals, figures in italics) of the Quarry Cave rodent species in the whole sample and two sieve fractions. Species are listed by size of first upper molar from smallest at the top to largest at the bottom.

\begin{tabular}{|c|c|c|c|c|c|c|}
\hline \multirow[b]{2}{*}{ Species } & \multicolumn{2}{|c|}{ Whole sample } & \multicolumn{2}{|c|}{$3 \mathrm{~mm}$ sieve only } & \multicolumn{2}{|c|}{$3 \mathrm{~mm}+1.63 \mathrm{~mm}$ siev } \\
\hline & NISP & $\%$ & NISP & $\%$ & NISP & $\%$ \\
\hline Pseudomys hermannsburgensis & 427 & 26.94 & 184 & 25.17 & 255 & 20.17 \\
\hline Pseudomys chapmani & 129 & 8.14 & 48 & 6.57 & 57 & 4.51 \\
\hline Leggadina sp. cf. L. lakedownensis & 66 & 4.16 & 37 & 5.06 & 51 & 4.03 \\
\hline Notomys alexis & 138 & 8.71 & 48 & 6.57 & 133 & 10.52 \\
\hline Pseudomys desertor & 57 & 3.60 & 17 & 2.33 & 52 & 4.11 \\
\hline Pseudomys fieldi & 70 & 4.42 & 21 & 2.87 & 67 & 5.30 \\
\hline Pseudomys nanus & 263 & 16.59 & 79 & 10.81 & 214 & 16.93 \\
\hline Rattus tunneyi & 201 & 12.68 & 119 & 16.28 & 201 & 15.90 \\
\hline Notomys longicaudatus & 205 & 12.93 & 157 & 21.48 & 205 & 16.22 \\
\hline Zyzomys pedunculatus & 23 & 1.45 & 16 & 2.19 & 23 & 1.82 \\
\hline Leporillus conditor & 3 & 0.19 & 3 & 0.41 & 3 & 0.24 \\
\hline Mesembriomys macrurus & 3 & 0.19 & 2 & 0.27 & 3 & 0.24 \\
\hline Totals & 1585 & 100.00 & 731 & 100.01 & 1264 & 99.99 \\
\hline$X^{2}$ & & & 83. & & 72. & \\
\hline$P=$ & & & $<0$ & & $<0$ & \\
\hline
\end{tabular}


reverted to $\lambda$ (rather than $C$ ) as the symbol for the index of concentration, as used by Simpson (1949). The results (Table 3) show that the $3 \mathrm{~mm}+1.63 \mathrm{~mm}$ fraction is both the most even and most heterogeneous, and that the whole sample is intermediate between it and the $3 \mathrm{~mm}$ fraction on both measures. But all have the same species richness, and overall the differences in the values of the indices are small, suggesting that little bias has been introduced.

\section{ANALYSIS OF ISOLATED FIRST MOLARS OF TWO RODENTS AT THE THRESHOLD OF RETENTION ON THE 3 MM SIEVE}

As noted above, Figures 5 and 6 show that the isolated first molars of the three rat-sized species lie at the threshold of retention on a $3 \mathrm{~mm}$ sieve. Sample sizes of only two of them, Rattus tunneyi and Notomys longicaudatus, however, are large enough to investigate in detail. Four measurements were made on each isolated molar (Appendix Tables A5 and A6), and the molar was assigned to one of five age classes based on the criteria in Appendix Table A4. The standard measurements of crown length and crown width (excluding teeth in which damage affected either of those dimensions) are summarised in Table 4. In every case the means of both measurements of molars retained by the $3 \mathrm{~mm}$ sieve, upper and lower in both species, are slightly larger than those of the molars that were not retained, but the difference is always less than one standard deviation, and in many instances much less. This is consistent with the general pattern that smaller teeth (of smaller species) are more likely to fall through the sieve (e.g. Figure 5).

TABLE 3 Quantified measures of the species richness ( $S$, number of species), evenness (Simpson diversity index, $1 / \lambda$; where $\lambda=\sum p_{i}^{2}$ ) and heterogeneity (Shannon index, $H=-\sum p_{i} \ln p_{i}$ ) of the Quarry Cave rodent assemblages in the whole sample and two sieve fractions.

\begin{tabular}{llll} 
& Whole sample & $3 \mathrm{~mm}$ sieve only & $3 \mathrm{~mm}+1.63 \mathrm{~mm}$ sieves \\
\hline Species richness $(S)$ & 12 & 12 & 12 \\
Evenness $(1 / \lambda)$ & 6.5651 & 6.2219 & 7.1159 \\
Heterogeneity $(H)$ & 2.0694 & 2.0340 & 2.1058 \\
\hline
\end{tabular}

TABLE 4 Crown lengths and crown widths (in millimetres) of isolated first molars of Rattus tunneyi and Notomys longicaudatus from Quarry Cave, excluding crowns with damage affecting either of those dimensions.

\begin{tabular}{|c|c|c|c|c|c|}
\hline & $3 \mathrm{~mm}$ sieve & Mean & $\begin{array}{l}\text { Standard } \\
\text { deviation }\end{array}$ & Range & $n$ \\
\hline \multicolumn{6}{|l|}{ Rattus tunneyi } \\
\hline \multirow[t]{2}{*}{ Crown length first upper molars } & Retained & 3.231 & 0.102 & $2.96-3.40$ & 32 \\
\hline & Not retained & 3.224 & 0.163 & $2.86-3.52$ & 38 \\
\hline \multirow[t]{2}{*}{ Crown width first upper molars } & Retained & 2.160 & 0.087 & $2.00-2.30$ & 33 \\
\hline & Not retained & 2.108 & 0.072 & $1.92-2.28$ & 40 \\
\hline \multirow[t]{2}{*}{ Crown length first lower molars } & Retained & 2.806 & 0.106 & $2.62-2.94$ & 10 \\
\hline & Not retained & 2.720 & 0.097 & $2.52-2.90$ & 34 \\
\hline \multirow[t]{2}{*}{ Crown width first lower molars } & Retained & 1.820 & 0.124 & $1.62-1.96$ & 10 \\
\hline & Not retained & 1.795 & 0.103 & $1.60-2.06$ & 37 \\
\hline \multicolumn{6}{|l|}{ Notomys longicaudatus } \\
\hline \multirow[t]{2}{*}{ Crown length first upper molars } & Retained & 3.283 & 0.143 & $2.94-3.54$ & 39 \\
\hline & Not retained & 3.206 & 0.193 & $2.80-3.54$ & 14 \\
\hline \multirow[t]{2}{*}{ Crown width first upper molars } & Retained & 2.299 & 0.075 & $2.16-2.48$ & 44 \\
\hline & Not retained & 2.247 & 0.098 & $2.10-2.40$ & 14 \\
\hline \multirow[t]{2}{*}{ Crown length first lower molars } & Retained & 3.146 & 0.085 & $2.96-3.30$ & 24 \\
\hline & Not retained & 3.113 & 0.105 & $2.86-3.34$ & 19 \\
\hline \multirow[t]{2}{*}{ Crown width first lower molars } & Retained & 2.089 & 0.066 & $1.94-2.22$ & 28 \\
\hline & Not retained & 2.063 & 0.092 & $1.86-2.20$ & 30 \\
\hline
\end{tabular}


Plots of height against diagonal length (including measurements of damaged teeth), however, show more interesting patterns, particularly the isolated first upper molars of Rattus tunneyi (Figure 9).

While there is some 'noise' in Figure 9 from chance effects - the longest tooth was not retained (circular symbol, top right) and the shortest was retained (square symbol, bottom left) - there is a general pattern of retention of long, tall teeth and a loss of the smaller teeth. The age classes also correlate with this pattern: there is a preponderance of retained older individuals (open square symbols) in the upper right quarter of the plot, and not retained youngest age class (filled black circular symbols) in the lower left quarter.

The pattern in Figure 9 suggests that the threshold of retention for first upper molars of Rattus tunneyi lies just above $4.2 \mathrm{~mm}$ diagonal length. This distribution is explored in more detail in Figure 10, which is plotted using an abscissa that is common to all four such plots (Figures 10, 12, 14 and 16) to make them more easily comparable. Figure 10 shows that loss is much greater for teeth with a diagonal length less than $4.24 \mathrm{~mm}$, which is also the diagonal dimension of a $3 \mathrm{~mm}$ square sieve mesh aperture

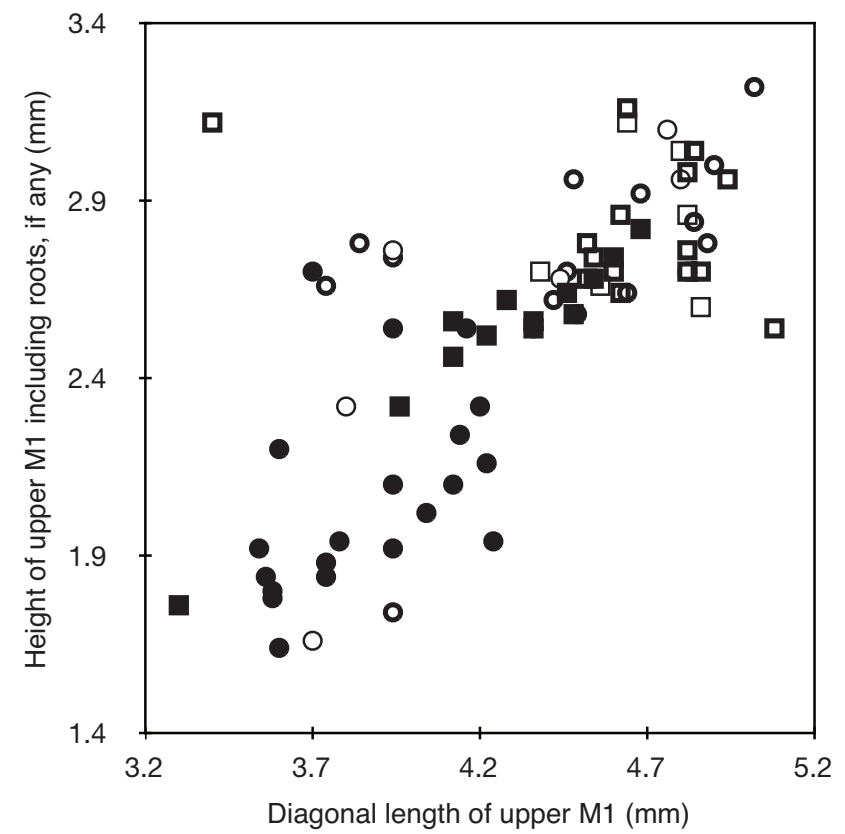

FIGURE 9 Bivariate scatter plot of height versus diagonal length of isolated first upper molars of Rattus tunneyi from Quarry Cave. Squares = retained on a $3 \mathrm{~mm}$ sieve; circles $=$ not retained. Filled black symbols $=$ age class 1 ; thick line open symbols $=$ age class 2 ; thin line open symbols $=$ age class $3+$. (more precisely $\sqrt{18}=4.2426+\mathrm{mm}$ ), and that the majority of the lost molars are age class 1 .

The plot of height against diagonal length of the isolated first lower molars of $R$. tunneyi (Figure 11) shows a much tighter correlation between the variables, and that the vast majority of those molars were not retained by the $3 \mathrm{~mm}$ sieve.

The distribution plot for the isolated lower molars (Figure 12) not only emphasises the high proportion of molars not retained, probably because most are below $4.24 \mathrm{~mm}$ diagonal length, but also shows that the youngest age class teeth were almost all among those lost.

Although the pattern in the isolated first upper molars in particular suggests that the differential recovery introduces a demographic bias, this is not statistically significant for those molars alone (Table 5a), probably because the sample size is too small. But when all first molars, both upper and lower, including those still in jaw bones (all of which were retained by the $3 \mathrm{~mm}$ sieve), are incorporated into the analysis, the result is statistically significant (Table 5b). Screening Rattus tunneyi material with a $3 \mathrm{~mm}$ sieve can bias the demographic structure of the retained specimens.

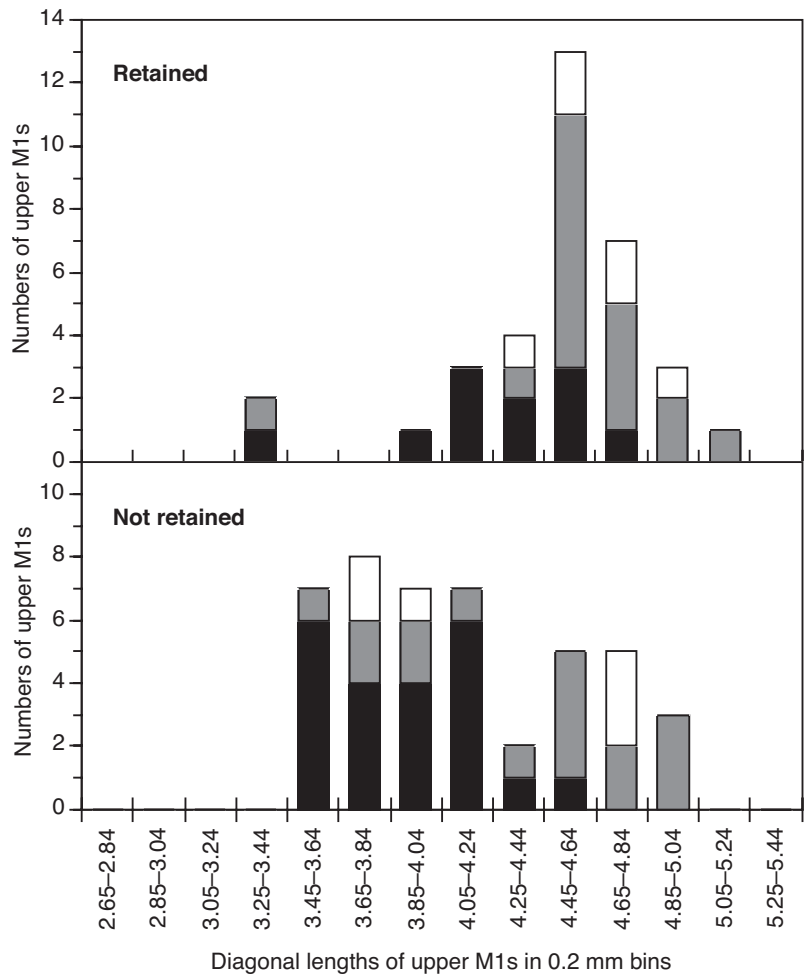

FIGURE 10 Distribution of diagonal lengths of isolated first upper molars of Rattus tunneyi from Quarry Cave, retained on a $3 \mathrm{~mm}$ sieve, or not retained, plotted in $0.2 \mathrm{~mm}$ bins. Black fill $=$ age class 1 ; grey fill $=$ age class 2 ; white fill $=$ age class $3+$. 


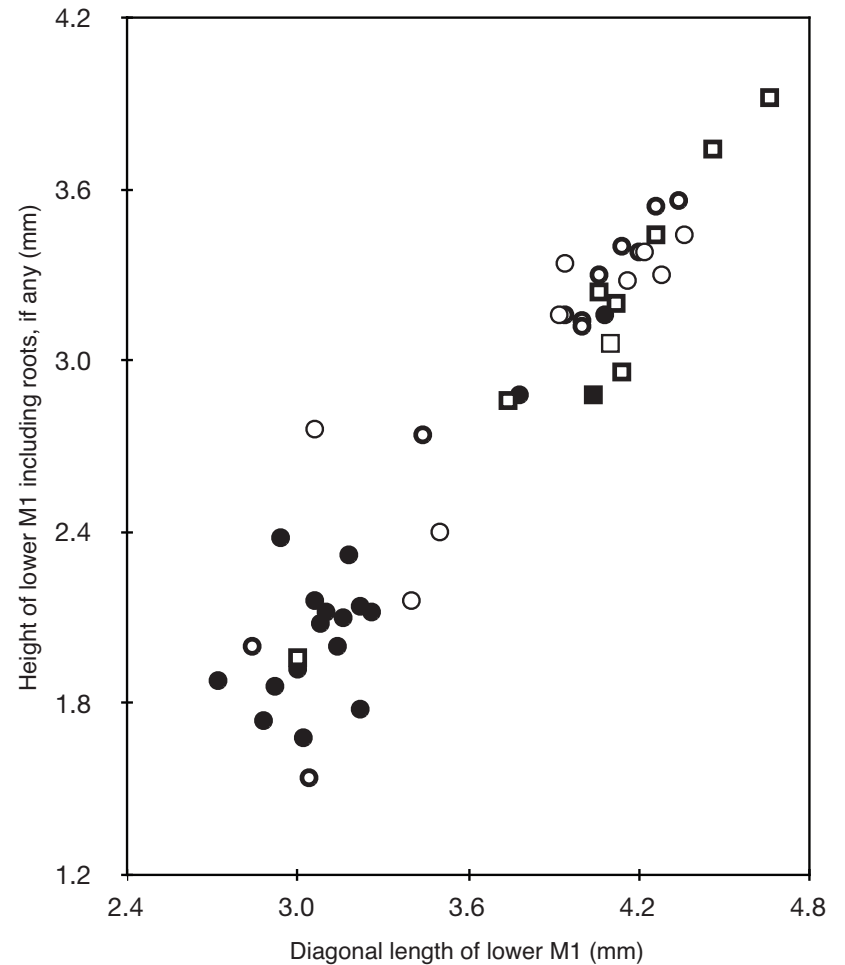

FIGURE 11 Bivariate scatter plot of height versus diagonal length of isolated first lower molars of Rattus tunneyi from Quarry Cave. Squares $=$ retained on a $3 \mathrm{~mm}$ sieve; circles $=$ not retained. Filled black symbols $=$ age class 1 ; thick line open symbols $=$ age class 2 ; thin line open symbols $=$ age class $3+$.

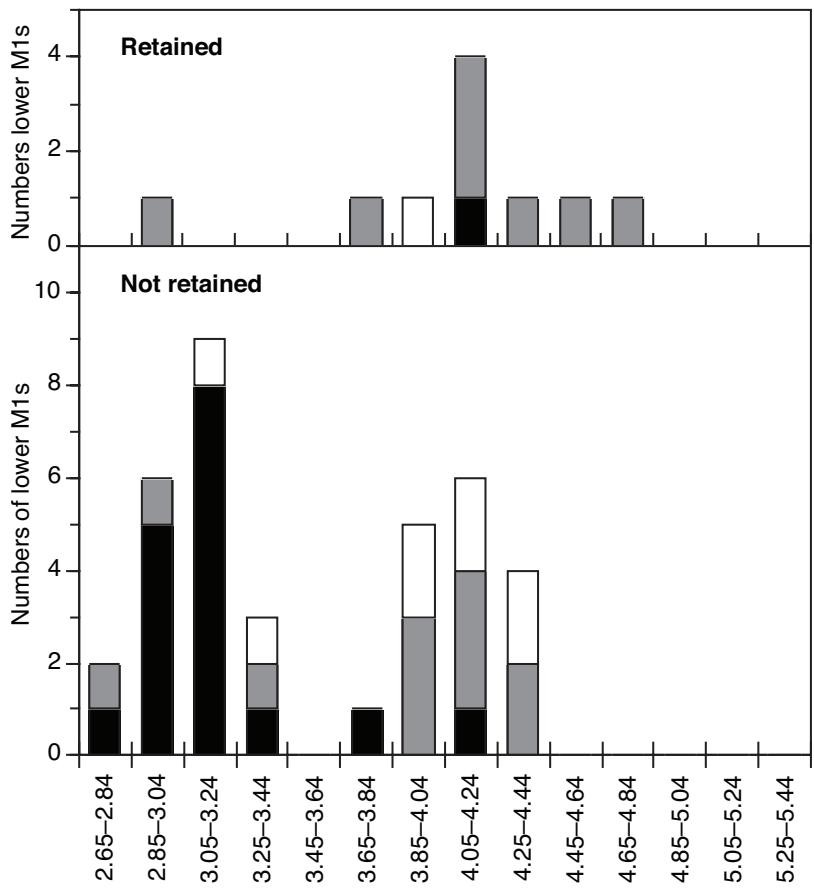

Diagonal lengths of lower M1s in $0.2 \mathrm{~mm}$ bins

FIGURE 12 Distribution of diagonal lengths of isolated first lower molars of Rattus tunneyi from Quarry Cave, retained on a $3 \mathrm{~mm}$ sieve, or not retained, plotted in $0.2 \mathrm{~mm}$ bins. Black fill = age class 1 ; grey fill = age class 2 ; white fill $=$ age class $3+$.

TABLE 5 Chi-square tests of statistical significance of the demographic pattern of (a) isolated first upper molars alone and (b) all first molars, upper and lower, including those still in jaw bones, of Rattus tunneyi from Quarry Cave, using the null hypothesis that age classes in the molars retained by the $3 \mathrm{~mm}$ sieve will be in the same proportion as in the whole sample (Total column). All calculated figures rounded.

Retained

\section{(a) Isolated first upper molars alone}

Age class 1

Age class 2

11

Age class 3+

Totals

$X^{2}$

$\mathrm{d}$ of $\mathrm{f}$

P

6

Total

Expected

$(O-E)^{2} / E$

0.7221

0.5510

14.2

0.0293

16

33

5.6

1.3025

1.303

2

$>0.5 \mathrm{NS}$

(b) All first molars, upper and lower, including those still in jaw bones

Age class 1

Age class 2

Age class 3

Age class 4+

Totals

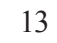

58

39

27

44

4

119

12

4

82

$X^{2}$

$\mathrm{d}$ of $\mathrm{f}$

$P$

$\begin{array}{rcc}52 & 30.8 & 10.2756 \\ 85 & 50.3 & 1.1710 \\ 56 & 33.2 & 3.5480 \\ 8 & 4.7 & 0.1145 \\ 201 & 119 & 15.1091 \\ & & 15.109 \\ & & 3 \\ & & <0.005\end{array}$




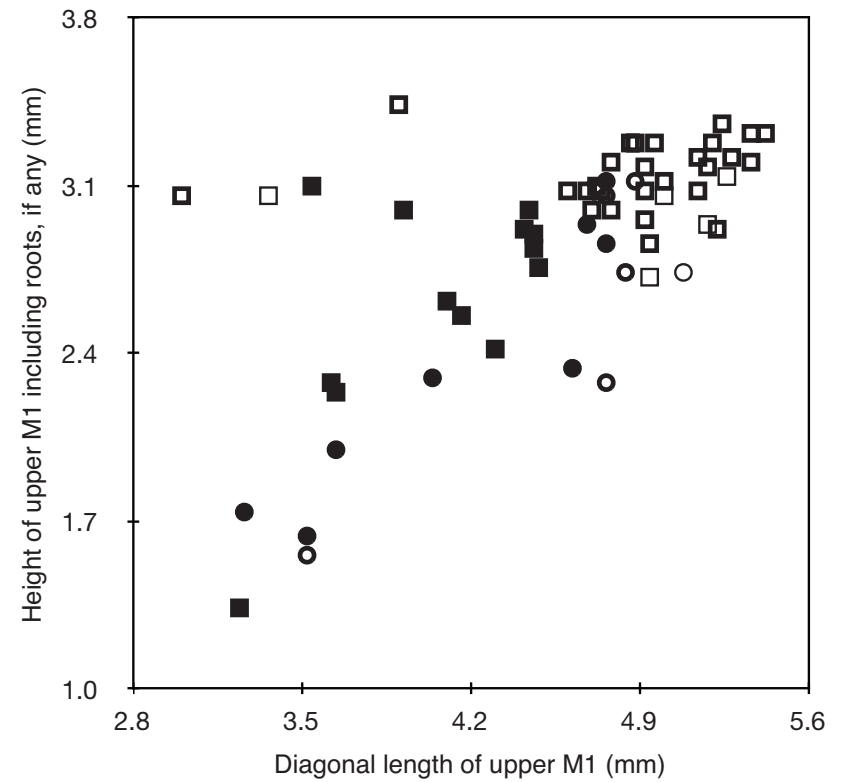

FIGURE 13 Bivariate scatter plot of height versus diagonal length of isolated first upper molars of Notomys longicaudatus from Quarry Cave. Squares $=$ retained on a 3 $\mathrm{mm}$ sieve; circles $=$ not retained. Filled black symbols $=$ age class 1 ; thick line open symbols = age class 2 ; thin line open symbols $=$ age class $3+$.

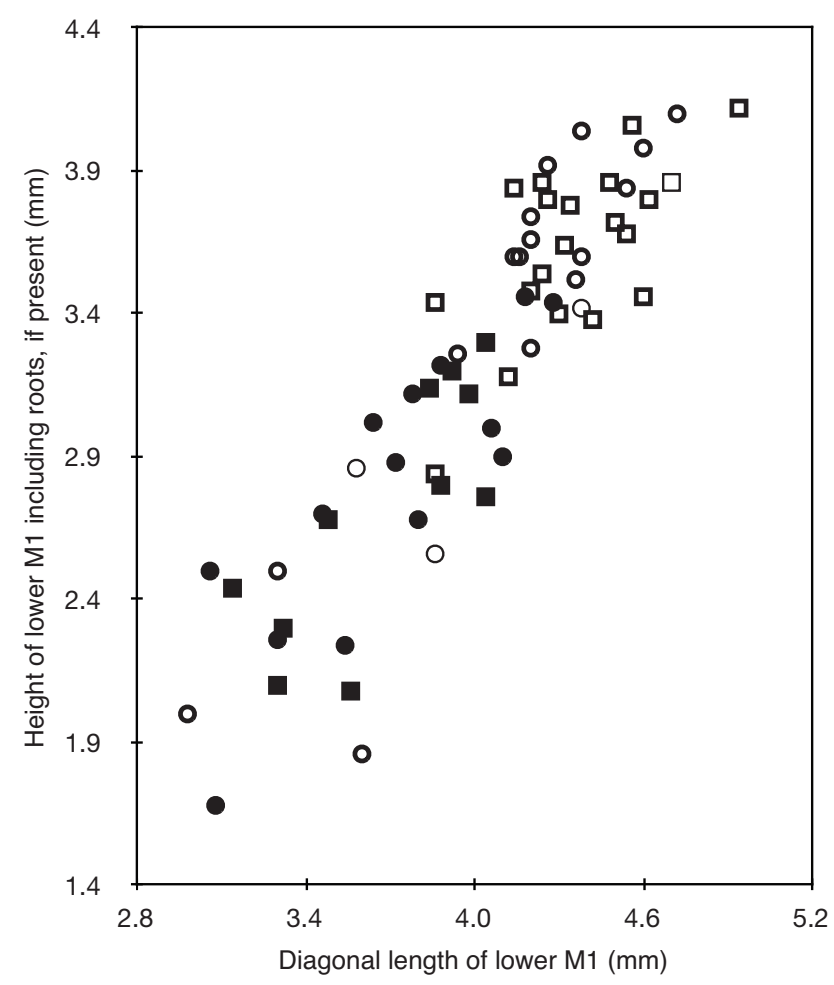

FIGURE 15 Bivariate scatter plot of height versus diagonal length of isolated first lower molars of Notomys longicaudatus from Quarry Cave. Squares $=$ retained on a 3 $\mathrm{mm}$ sieve; circles $=$ not retained. Filled black symbols $=$ age class 1 ; thick line open symbols = age class 2 ; thin line open symbols $=$ age class $3+$.

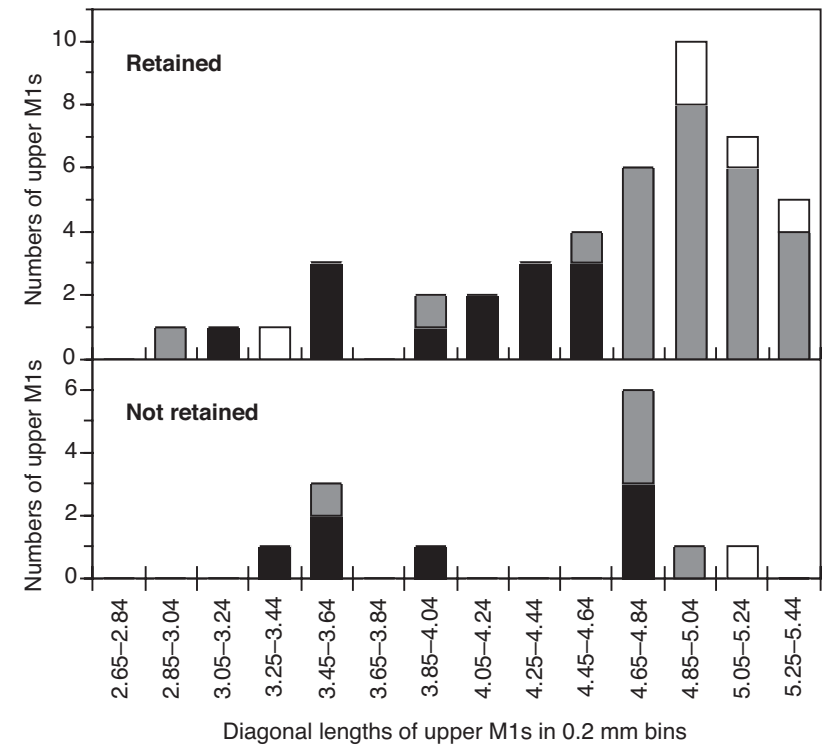

FIGURE 14 Distribution of diagonal lengths of isolated first upper molars of Notomys longicaudatus from Quarry Cave, retained on a $3 \mathrm{~mm}$ sieve, or not retained, plotted in $0.2 \mathrm{~mm}$ bins. Black fill = age class 1 ; grey fill $=$ age class 2 ; white fill $=$ age class $3+$.

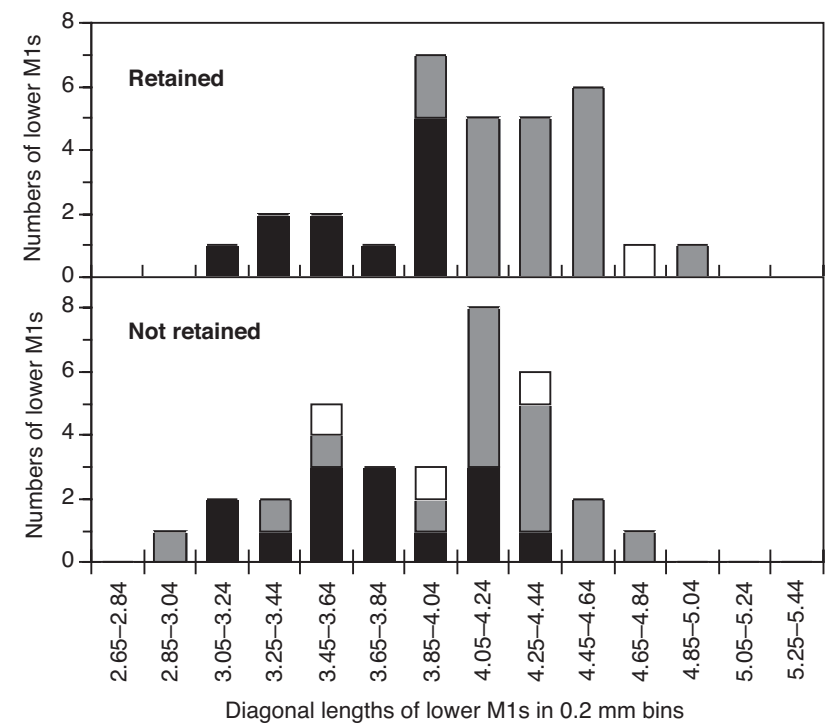

FIGURE 16 Distribution of diagonal lengths of isolated first lower molars of Notomys longicaudatus from Quarry Cave, retained on a $3 \mathrm{~mm}$ sieve, or not retained, plotted in $0.2 \mathrm{~mm}$ bins. Black fill = age class 1 ; grey fill = age class 2 ; white fill = age class $3+$. 
The isolated molars of Notomys longicaudatus were measured in the same way as those of Rattus tunneyi. The crown lengths and crown widths of $N$. longicaudatus molars show the same pattern as those of $R$. tunneyi (see Table 4). Heights versus diagonal lengths of the upper molars of N. longicaudatus are plotted in Figure 13.

The points group in the top right quarter of Figure 13 , probably because, although the upper molars of $N$. longicaudatus are only slightly larger than those of $R$. tunneyi, most of the teeth were retained, as emphasised by Figure 14.

Heights versus diagonal lengths of the lower molars are plotted in Figure 15, which shows a fairly tight correlation between the dimensions, and that retained and lost teeth are fairly evenly distributed through the size range, as shown by the lack of a clear pattern in Figure 16.

Chi-square tests of the age class distributions of the $N$. longicaudatus molars yielded $X^{2}$ values of 0.883 for isolated uppers alone and 5.322 for all molars, returning statistically non-significant probabilities of $>0.5$ and $>0.1$, respectively. Demographic bias cannot be demonstrated in Notomys longicaudatus.

\section{CALADENIA CAVE RODENTS}

The fossil rodent fauna from Caladenia Cave includes seven abundant species consisting of one small mouse Pseudomys albocinereus (Ash-grey Mouse), three large mice Pseudomys occidentalis (Western Mouse), Pseudomys fieldi (Shark Bay Mouse), Notomys sp. indet. (small hopping-mouse), and three rats Pseudomys shortridgei (Heath Rat), Rattus fuscipes (Bush Rat) and Rattus tunneyi (Pale Field-rat). Isolated first molars, both upper and lower, of all seven can be distinguished at the species level. Results comparable to those from Quarry Cave were obtained when rodent remains originally recovered on a $1 \mathrm{~mm}$ sieve from the deposit in Caladenia Cave were gently dry-screened using a $3 \mathrm{~mm}$ sieve. The raw count data (Appendix Table A7) are plotted in Figure 17. Again, large proportions of most species fell through, including all specimens of both Rattus species.

\section{BOODIE CAVE, BARROW ISLAND}

The rodent results for the three sieve fractions from one particularly rich excavation unit in the A107 archaeological excavation in Boodie Cave on Barrow
Island (Veth et al. 2014, 2017), are shown in Table 6 (overleaf). An estimate of the live biomass of just the 1 $\mathrm{mm}$ fraction has been generated using mean adult body weight data. The $2 \mathrm{~mm}$ sieve recovered 29 times the number of rodent remains recovered by the $4 \mathrm{~mm}$, and the $1 \mathrm{~mm}$ recovered 27 times that recovered by the 2 $\mathrm{mm}$. That is to say, if the smallest sieve used had been the $2 \mathrm{~mm}$, over $96 \%$ of the rodent specimens would have been lost, a point emphasised by Figure 18.

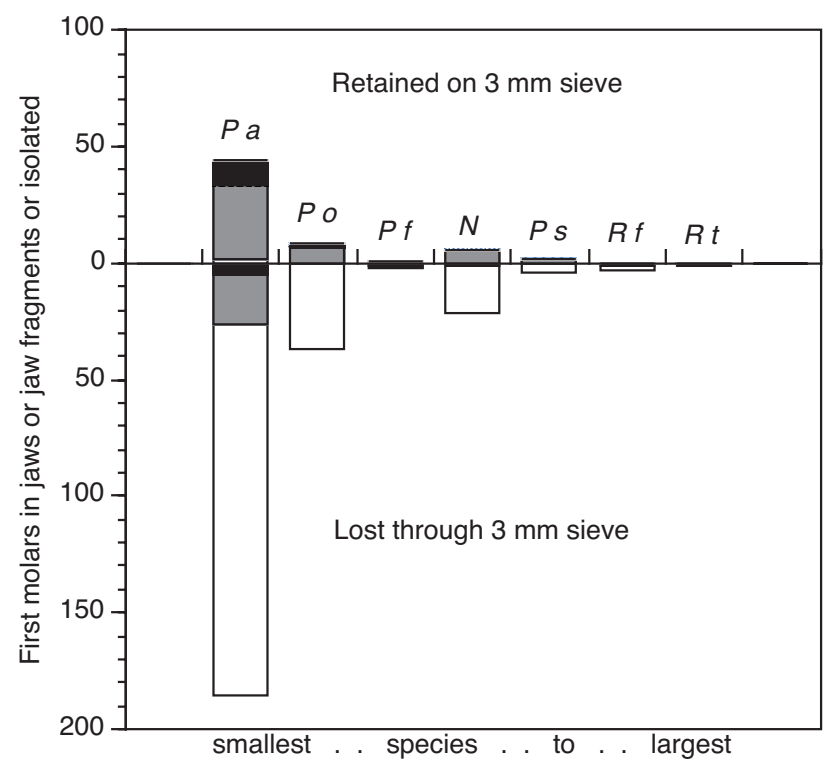

FIGURE 17 Combined numbers of upper and lower first molar teeth in complete jaws (black fill), in jaw bone fragments (grey fill) or isolated first molars (white fill), retained by (above the horizontal line) or lost through (below the line) a $3 \mathrm{~mm}$ sieve, represented by the horizontal line across the middle of the figure, from seven rodent species from Caladenia Cave, arranged by size of first upper molar from smallest on the left to largest on the right. The species are, left to right: Pseudomys albocinereus $(P$ a), Pseudomys occidentalis ( $P$ o), Pseudomys fieldi ( $P$ f), Notomys sp. indet. (N), Pseudomys shortridgei ( $P$ s), Rattus fuscipes ( $R f$ ) and Rattus tunneyi $(R t)$.

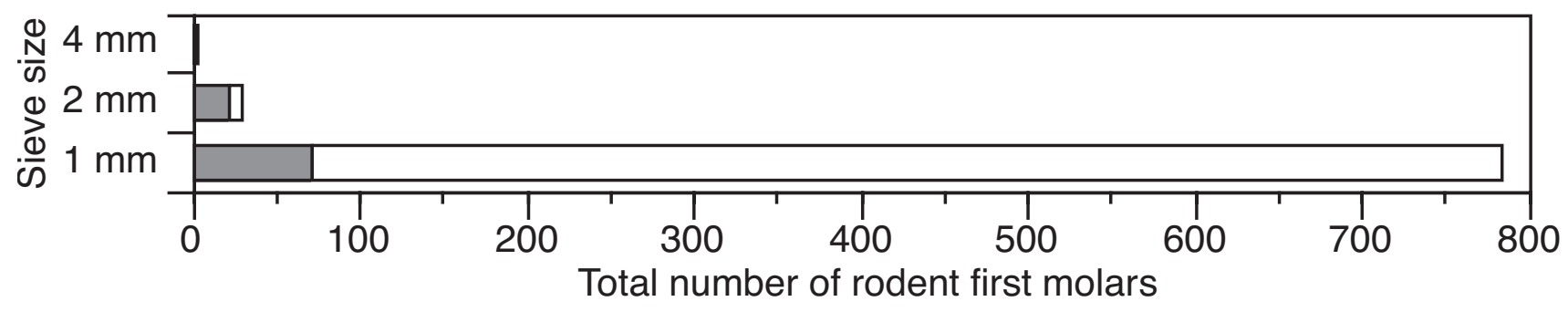

FIGURE 18 Total numbers of rodent first molars in jaw bone fragments (grey fill) or as isolated teeth (white fill) in each of three wet-screened sieve fractions from unit 34 of the A107 archaeological excavation in Boodie Cave, Barrow Island, Western Australia. Data from Table 6. 
TABLE $6 \quad$ NISP and MNI of rodent first molars in three immersion wet-screened sieve fractions from unit 34 of the A107 archaeological excavation in Boodie Cave, Barrow Island, Western Australia (Veth et al. 2014, 2017). NISP data combine upper and lower and left and right molars. The numbers in brackets are the portions of the NISP for each species that are in jaw bone fragments. Species are arranged in order of first molar size from smallest at the top to largest at the bottom. Weight data sourced from species accounts by relevant authors in Strahan (1995).

\begin{tabular}{|c|c|c|c|c|c|c|c|}
\hline & \multirow{2}{*}{$\begin{array}{l}4 \mathrm{~mm} \text { sieve } \\
\text { NISP }\end{array}$} & \multicolumn{2}{|c|}{$2 \mathrm{~mm}$ sieve } & \multicolumn{2}{|c|}{$1 \mathrm{~mm}$ sieve } & \multirow{2}{*}{$\begin{array}{r}\text { Weight } \\
(\mathrm{g})\end{array}$} & \multirow{2}{*}{$\begin{array}{r}1 \mathrm{~mm} \text { live } \\
\text { biomass }(\mathrm{g})\end{array}$} \\
\hline & & NISP & MNI & NISP & MNI & & \\
\hline Pseudomys delicatulus & 0 & $5(4)$ & 3 & $298(30)$ & 92 & 10 & 920 \\
\hline Pseudomys hermannsburgensis & 0 & $10(10)$ & 5 & $198(28)$ & 54 & 12 & 648 \\
\hline Pseudomys chapmani & 0 & $2(2)$ & 2 & $65(7)$ & 18 & 12 & 216 \\
\hline Leggadina sp. cf. L. lakedownensis & 0 & $2(1)$ & 1 & $33(5)$ & 12 & 17 & 204 \\
\hline Zyzomys argurus & 0 & 0 & 0 & $1(0)$ & 1 & 36 & 36 \\
\hline Notomys alexis & 1(1) & $2(1)$ & 2 & $66(5)$ & 22 & 35 & 770 \\
\hline Pseudomys desertor & 0 & $1(0)$ & 1 & $18(0)$ & 6 & 25 & 150 \\
\hline Pseudomys fieldi & 0 & $1(1)$ & 1 & $12(0)$ & 4 & 40 & 160 \\
\hline Pseudomys nanus & 0 & $1(1)$ & 1 & $64(0)$ & 17 & 34 & 578 \\
\hline Rattus tunneyi & 0 & $2(1)$ & 1 & $15(0)$ & 5 & 120 & 600 \\
\hline Notomys longicaudatus & 0 & $3(1)$ & 3 & $6(0)$ & 5 & 80 & 400 \\
\hline Zyzomys pedunculatus & 0 & 0 & 0 & $4(0)$ & 2 & 110 & 220 \\
\hline Notomys amplus & 0 & 0 & 0 & $3(0)$ & 1 & 100 & 100 \\
\hline Totals & 1(1) & $29(22)$ & 20 & $783(71)$ & 239 & & 5002 \\
\hline$\%$ of total NISP & 0.12 & 3.57 & & 96.31 & & & \\
\hline
\end{tabular}

\section{DISCUSSION}

The $3 \mathrm{~mm}$ sieve experimental set-up that we used for Quarry Cave materials differs in one important aspect from wet-screening excavated sediments under field conditions, when carried out by placing nested screens in a water bath and repeatedly raising and lowering them until loss of fine sediment ceases. This gives multiple opportunities for larger particles such as bones or teeth to be lifted by the water from the mesh surface and change orientation, increasing their chances of presenting their minimum dimensions to the mesh during the next cycle and falling through. In our set-up, water flowing from the hose probably moved specimens around on the sieve, but we suspect not as much as in immersed screening. On the other hand, because the Quarry Cave sediments had been in store for more than a decade they were very dry and required prolonged hosing to wet them and complete sieving of each batch, which probably increased movement. On balance it was probably less, and in particular less evenly spread across the sieve. That unevenness may explain such apparent anomalies as retention of the smallest isolated upper molar of each of Rattus tunneyi and Notomys longicaudatus (Figures 9 and 13).
Materials in Quaternary fossil assemblages almost always show some degree of fragmentation. The taphonomic histories of archaeological accumulations often cause severe fragmentation (e.g. Thomas 1969; Shaffer 1992; Muckle 1994; Nagaoka 2005), in particular due to human food extraction techniques (e.g. NoeNygaard 1977) and trampling (e.g. Gifford-Gonzalez et al. 1985). Apart from often dislodging the first molar teeth, damage to murid jaws causes changes in overall shape which in turn increase the probability of the bones falling through sieves. A dissociated but unbroken murid maxilla is roughly the shape of a pyramid with a threesided base. The proximal zygomatic arch on the maxilla from a small murid can act like a grappling-hook and catch on the wire mesh of a sieve while the rest of the bone falls through, as observed during our experiments. If the relatively fragile zygomatic plate has been broken off, the remaining alveolar plate, with or without molars, is approaching rod-shaped and able to fall through a much smaller aperture. A complete lower jaw is roughly disc-shaped, and slightly larger and somewhat more robustly built than a maxilla from the same species, so would be expected to be less fragmented and more likely to be retained. While our Quarry Cave results did show greater retention of lower than upper first molars by the 
$3 \mathrm{~mm}$ sieve (Figure 6), this was mainly because a higher proportion of lower first molars remained in jaw bones.

The degree of fragmentation of the murid jaws from the Quarry Cave deposit is intermediate between the severe level often found in archaeological deposits and the intact bone of fully protected owl accumulations. The bone is fairly fragile, probably because of the relatively damp conditions of the nearly enclosed cave. The most important fragmenting agents were probably six subadult Petrogale lateralis (Black-flanked Rockwallabies), which had apparently squeezed in through the shallow entrance but were then unable to escape from the cave, and whose skeletons were found lying on the floor surface. They probably roamed around looking for an exit before succumbing to starvation and/or dehydration. The small mammal bone also shows a few more recent breaks inflicted by the shovel used for bulk sample collection. The murid jaw bones from Quarry Cave are nevertheless almost all sufficiently intact to be identifiable to species even after they have lost their first molar teeth, which is in strong contrast to much of the bone from many archaeological deposits.

Preservation of bone material in the Caladenia Cave deposit is good at the surface but deteriorates towards the bottom of the deposit, where the bone is dark brown and sufficiently fragile that some fragmentation would have been caused by excavation. The effect of a $3 \mathrm{~mm}$ sieve could only be investigated using rodent remains originally collected on the $1 \mathrm{~mm}$ sieve, and that was only used for the lower layers. The fragmentation probably increased the (large) proportion of specimens that fell through (Figure 17). These included all specimens of both species of Rattus, which would not have been recorded in the fauna of that spit if the $3 \mathrm{~mm}$ sieve had been used at the time of excavation. The deposit does include a minor archaeological component (Monks et al. 2014; Thorn et al. 2017), and some fragmentation of bones of larger fauna such as macropods was probably caused by humans, but the small mammals were mainly accumulated by owls and their bones were probably fragmented by other taphonomic factors, possibly including trampling.

The results of the sieving experiments clearly show that, if the bone material in a deposit is at all fragmented, a $3 \mathrm{~mm}$ sieve (the metric equivalent of $1 / 8$ th inch) is not fine enough to recover key identifiable skeletal remains of Australian native rodents, without biasing the results to a highly statistically significant extent (Table 2). Nor is a 1.63 $\mathrm{mm}$ sieve (the approximate metric equivalent of $1 / 16$ th inch) fine enough to completely recover the isolated first molar teeth of all species smaller than rats. Such molars may become isolated as a result of separation from the jaw bones during digestion or mastication by a predator, preparation of human food, pre-depositional mechanical damage of the jaws on the cave floor surface, or weakening of jaw bone by chemical processes in the deposit, especially in the deeper layers, followed by disintegration in the rigours of excavation and/or sieving (especially dry sieving).

Our results show that there is significant inter-species variation in the way in which this differential recovery affects Australian rodents. For example, as illustrated in Figure 6, the five species of Pseudomys, the Rattus and the Zyzomys from Quarry Cave show a common pattern of greater loss of upper molars than lower molars through a $3 \mathrm{~mm}$ sieve, whereas Leggadina and Notomys longicaudatus show the opposite pattern of greater loss of lower molars, and in Notomys alexis they are equal. These patterns probably reflect the morphologies of the molar teeth. Upper molars of those five species of Pseudomys, Rattus tunneyi and the Zyzomys are all relatively low-crowned, with strongly backward sloping cusps, short vertical posterior and lingual roots but less vertical anterior roots, whereas the upper molars of both species of Notomys have relatively tall crowns with more upright cusps and relatively vertical roots. The lower molars of all those species have taller crowns and more robust and vertical roots than the upper molars of the same species. The Leggadina appears anomalous because it too has low-crowned upper molars, but it also has low-crowned lower molars, and it is the only species in which a higher proportion of the lower molars than the upper molars is separated from its jaw bones (Figure $6)$. The variation in retention on sieves in turn affects the patterns of relative abundance (Figure 8).

The differential recovery does not, however, appear to substantially bias indices of rodent diversity calculated from the various sieve fractions (Table 3 ). This may be partly because the coarsest sieve used, the $3 \mathrm{~mm}$, is fine enough to retain substantial numbers of remains of all of the rodent species in the Quarry Cave assemblage, but also because the rodents are only one component of the mammal assemblage, which includes remains of medium-sized insectivorous/omnivorous marsupials (bandicoots) and small carnivorous/insectivorous marsupials (dasyurids) each of which would have different recovery properties. Diversity indices for the full assemblage might show greater bias.

Measurement of the isolated molars of Rattus tunneyi and Notomys longicaudatus from Quarry Cave yielded two clear results. It confirmed the suggestion by Lyman (2012) that the diagonal dimension of the sieve mesh is at least as important in retention or loss of small objects as the side dimension. It also demonstrated that differential recovery can bias the demographic composition of retained specimens to a statistically significant extent (Table 5), but only if the morphological structures in question change in size with age and/or taphonomic history and their size range precisely spans the threshold of retention. The freshly erupted molars of subadult murids have short, 
very thin-walled open roots which are fragile and more likely to be further shortened or even removed completely by breakage, leaving only an enamel crown, during separation or post-depositional handling, further reducing the size of the teeth and making them more likely to be lost through a sieve. This was epitomised by a specimen of the largest molar of the largest rodent in the Quarry Cave fauna falling through the $3 \mathrm{~mm}$ sieve, because its roots had been broken off leaving a rod-shaped crown. In contrast, molars from older individuals of all murids have closed, longer, sturdier roots which are less likely to be broken (see also Figure 4), making the teeth more likely to be retained on a sieve if isolated, but also more likely to remain in jaw bones.

Recent remains of Rattus tunneyi from sites along the west coast of Australia show a cline in upper molar size (Baynes 1989). The animals in the population that originally occurred on the northern Swan Coastal Plain, between latitudes $29^{\circ} \mathrm{S}$ and $32^{\circ} \mathrm{S}$, were larger than those from Quarry Cave (at about $22^{\circ} \mathrm{S}$ latitude), probably because in that more southern region they were sympatric with the smaller Rattus fuscipes, the Bush Rat of southern Australia. The crown widths of first upper molars of $R$. tunneyi from a cave in $30^{\circ} \mathrm{S}$ latitude average $2.41 \mathrm{~mm}$ (range 2.24-2.57 $\mathrm{mm}, n=$ 58; unpublished data of Baynes), which is considerably larger than the Quarry Cave first upper molars (mean crown width $=2.16 \mathrm{~mm}$, range $1.92-2.30, n=73$; Table 4), with hardly any overlap. Assuming that the proportions of the molars of the southern population are the same as those from Quarry Cave, this suggests that their mean diagonal length would be about 4.80 $\mathrm{mm}$, even larger than the Quarry Cave Notomys longicaudatus mean of $4.57 \mathrm{~mm}$, and too large for screening with a $3 \mathrm{~mm}$ sieve to bias the demographic structure of that population of $R$. tunneyi, because they would not span the threshold of retention. This suggests that the effects of differential recovery can differ as a result of intra-specific variability as well as the interspecific variability noted above.

Demographic effects can be important in the analysis of any assemblage in which age class representation is integral to its interpretation. For example, the isolated molars of Notomys amplus (Short-tailed Hoppingmouse) from an archaeological excavation in Morgan's Cave, on the Montebello Islands off north-western Australia (see Figure 1) (Veth 1993), included high proportions of completely or nearly unworn isolated enamel crowns compared to both conspecific material from an owl accumulation and other rodent species from the same deposit (Piper 2014). This led to the suggestion that they might have come from pre-recruit nestling animals dug from their burrows by humans for food, rather than owl predation. But the alternative explanation for the apparently anomalous pattern is that $N$. amplus has the largest molars in that rodent fauna, and it was the only species in the assemblage whose isolated molar crowns from the most juvenile individuals were retained by the $3 \mathrm{~mm}$ sieve when dry screened (Piper 2014). On the other hand, if immersion wet screening is used, providing the opportunity for multiple orientations, isolated enamel crowns of $N$. amplus are not retained by even a $2 \mathrm{~mm}$ sieve (Table 6).

The experimental results show that the optimum sieve size for recovery of identifiable Australian murid remains lies between $0.71 \mathrm{~mm}$ and $1.63 \mathrm{~mm}$. The faunal results from Boodie Cave on Barrow Island (Table 6) demonstrate that a $1 \mathrm{~mm}$ sieve is adequate to recover isolated first molars of all Australian native rodents because Pseudomys delicatulus (Delicate Mouse) is the smallest extant species of rodent in Australia (Braithwaite and Covacevich 1995), with the smallest molars. They also show that when the molars are reduced to just enamel crowns and immersed wetscreening is used, a $2 \mathrm{~mm}$ sieve fails to recover most of the isolated teeth of not only mice but rat-sized rodents as well (up to and including the two largest rodent species in that Barrow Island sample). In this context, it is also noteworthy that Mus musculus (the introduced House Mouse), whose presence in a fauna is an important indicator of European settlement, has larger first molars, both upper and lower, than $P$. delicatulus, so identifiable remains of that species should also be retained by a $1 \mathrm{~mm}$ sieve. A $1 \mathrm{~mm}$ sieve may not, however, be fine enough to retain diagnostic teeth of tiny marsupials, such as species of Planigale or Ningaui, also present in many Australian owl accumulations, and is almost certainly too coarse to retain diagnostic bones of small lizards such as the frontal, maxilla and quadrate or the several bones that make up the lower jaws, because all are long and narrow.

The results also clearly show that Australian rodent faunal lists and relative abundance data based upon material recovered using sieves with a mesh aperture larger than $1 \mathrm{~mm}$, will exhibit all the kinds of bias identified by previous studies of differential recovery, detailed in the Introduction; and that these will be magnified by both increasing mesh size and level of fragmentation of the fossil assemblage.

It is half a century since Ziegler (1965) and Thomas (1969) advocated quantitative treatment of faunal remains, as well as artefacts, from archaeological deposits, and Payne (1972) pointed out that coarse sieves reduce the sample sizes of fine materials available for investigation. Subsequent advances in ecological theory have elucidated the relationship between sample size and the number of species recorded in a fauna (e.g. May 1975; Gotelli and Colwell 2001; Lyman and Ames 2007). Assemblages typically contain remains of 'core' species that are resident in the habitats that surround the sampling point and are persistent and generally abundant, plus vagrant species 
that inhabit more distant habitats or are beyond their normal range limits, or both, and are usually rare to very rare in the sample (Magurran and Henderson 2003; Sgarbi and Melo 2018). But large sample sizes are needed to detect the presence of the rarest species (e.g. Wolff 1975). Rare species can sometimes provide very important palaeoenvironmental information. For example, detection of Onychogalea unguifera (Northern Nail-tail Wallaby) in a midden deposit on the Montebello Islands (Veth et al. 2007), suggests that the poleward movement of the Australian summer monsoon in the early Holocene (Reeves et al. 2013) enabled this species to briefly extend its distribution at about $8 \mathrm{ka}$ west-south-westward along what was then the northern coast of the mainland, by more than $600 \mathrm{~km}$ compared to its present western range limit in Kimberley (see Figure 1) (Piper 2014; Manne and Veth 2015). Samples that are large enough for their rarefaction curves to approach an asymptote are also highly desirable as input to multivariate analyses, such as correspondence analysis or non-metric multidimensional scaling, which are becoming standard in the investigation of faunal materials in both archaeological and palaeontological assemblages.

Loss of small fauna through differential recovery can have major effects on inferences made by archaeologists about prehistoric economies and subsistence strategies (e.g. Gordon 1993; Nagaoka 1994; James 1997), by causing serious underestimation of the importance of the small species as human food (e.g. Stahl 1996; James 1997; Stewart and Wigen 2003). The 239 MNI of rodents in the $1 \mathrm{~mm}$ fraction from XU34 of the A107 excavation in Boodie Cave (Table 6) represent some $3-5 \mathrm{~kg}$ of live biomass (depending upon what proportion of the individuals were subadult). If they are the remains of human food, that would be a not insignificant resource to be evaluated in conjunction with remains of other foods from the same excavation unit, including large marsupials, and would not have been taken into consideration if only 4 and $2 \mathrm{~mm}$ sieves had been used.

The value of palaeontological assemblages from archaeological excavations as sources of ecological information also is diminished by differential recovery. This particularly applies in Australia where many of the native mammal species have become extinct, or have undergone enormous reductions in geographic range, since European settlement (Woinarski et al. 2015). For example, of the 14 rodent species recorded from Quarry Cave (including two only found in different bulk sample bags than that used for the experiment) the 10 largest are locally extinct, five of those are extinct throughout the Australian mainland (though two survive on one island each) and one (Zyzomys pedunculatus) is almost extinct (the whereabouts of only a single living population is currently known). As a result, it is no longer possible to make natural history observations on living populations of a substantial proportion of the species in their original communities, and remains have to be used to infer pre-European distributions (e.g. Baynes and Baird 1992; Baynes and McDowell 2010), and ecological relations (e.g. Baynes 1982; Bilney et al. 2010). For some species even their habitat requirements need to be inferred, by comparing relative abundances of species in bulk samples from assemblages, with the proportions of different substrates within the catchments of their accumulating agents (Baynes and Johnson 1996). Such data inferred from palaeontological investigations are then used to make palaeoenvironmental interpretations of faunal results from assemblages from Australian archaeological deposits (e.g. Veth et al. 2007). The reliability of such inferences will, however, be reduced if the data from the faunas, archaeological or palaeontological, are heavily biased by differential recovery, compared to the assemblages in the deposits before excavation, affecting the relative abundances of some species more than others (e.g. Gordon 1993; Nagaoka 1994). In particular, abundance and taphonomic data that might have been used to distinguish owl-accumulated fauna from human food can be compromised if substantial proportions of remains of the small species have not been recovered (e.g. Stahl 1996). The smallest sieve size used in the Montebello excavations was $3 \mathrm{~mm}$ (Veth 1993; Veth et al. 2007). Fragmentation of mammal remains in the deposits is severe, with many rodent jaws reduced to first molar alveolar fragments, often lacking molars and therefore usually unidentifiable to species (Piper 2014). The low relative abundances recorded for the smallest rodent species from two of the caves (Veth et al. 2007; Piper 2014), compared to nearby Quarry Cave and Boodie Cave, strongly suggest significant differential recovery effects. The results of our experiments confirmed that there are not only large losses of Australian rodent material through a $3 \mathrm{~mm}$ sieve, but even a $1.63 \mathrm{~mm}$ sieve for all species smaller than rats, and that these losses are highly statistically significant for both sieve sizes. Changes in relative abundance of species in a deposit caused by local environmental changes can be quite subtle in Australia, where late Quaternary climatic changes have been less extreme than in higher, particularly northern, latitudes. As a result, the effects of differential recovery can easily overwhelm the environmental signal. For example, a change of sieve size during excavation of Caladenia Cave was revealed by correspondence analysis to be the paramount factor controlling patterns in the data (Thorn et al. 2017).

Although the need for reporting of full details of excavation methods was advocated by Payne (1972), many papers published as late as the 1980 s still did not include information on the sieve sizes used 
(Gordon 1993). A survey of a sample of the Australian archaeological literature shows that from the early 1990s details of sieve mesh size have usually been included in excavation reports (Table 7). Whether wet or dry sieving was used is less consistently reported. In compiling Table 7, it was generally assumed that dry sieving was used (listed as '?D') when neither was specified. It is perhaps surprising that the data do not show a more obvious trend towards finer sieves and gentler recovery techniques in recent years (cf. Ball and Bobrowsky 1987). Though this may be partly explained by the delay between excavation and publication. As early as 1991, the La Trobe school were wet-screening with nested 7, 3 and $1 \mathrm{~mm}$ sieves in Tasmania (Stern and Marshall 1993), whereas dry-screening with nested 6 and $3 \mathrm{~mm}$ sieves was still being used in Western Australia in 2007 (Law et al. 2010).

In this context, it is notable that when American palaeontologists Ernest L. Lundelius Jr and William D. Turnbull visited Australia in 1963-64 to excavate sites in both eastern and western Australia (e.g. Lundelius and Turnbull 1973), they brought with them a nested set of sieves with $7.0 \mathrm{~mm}, 2.5 \mathrm{~mm}$ and $0.5 \mathrm{~mm}$ mesh apertures, which had been built in the Field Museum of Natural History in Chicago (in litt. E.L.L. 23 Mar 2019). Those sieves are still in the field equipment of the Western Australian Museum Department of Earth and Planetary Sciences.

Two conflicting themes dominate the literature on differential recovery: how its biasing of faunal data from archaeological excavations can be so serious that it leads to false interpretations (e.g. Gordon 1993; James 1997) that can only be corrected by repeating the entire investigation (e.g. Stewart and Wigen 2003), versus how the need for better recovery has to be balanced against the monetary and logistical costs of field work (e.g. Thomas 1969; Casteel 1972; Payne 1972; Ball and Bobrowsky 1987; Lyman 2012). We suggest that a paradigm shift (in the sense of a fundamental change in approach) in Australia to less ambitious but more meticulous archaeology, in which all the contents of a deposit are given equal weight and priority, would represent better value for time and money, as well as being likely to enable more detailed and accurate interpretations to be made of materials recovered from the deposit. It is only when investigators can be certain that there is no bias being introduced by the recovery methods that natural biases in the data, such as those

TABLE 7 Recovery techniques used in a sample of Australian archaeological excavations.

\begin{tabular}{|c|c|c|c|c|c|}
\hline Site & $\begin{array}{c}\text { Year } \\
\text { excavation } \\
\text { begun }\end{array}$ & $\begin{array}{l}\text { Sieve size }(\mathrm{s}) \\
(\mathrm{mm})\end{array}$ & $\begin{array}{c}\text { Dry (D) } \\
\text { or } \\
\text { Wet (W) }\end{array}$ & $\begin{array}{c}\text { Fauna? } \\
\text { Yes or No }\end{array}$ & Reference \\
\hline Kutikina Cave & 1981 & 3 & $\mathrm{~W}$ & Yes & Garvey (2006) \\
\hline Monkey Mia shelters 1, 2 & 1986 & 5 & $? \mathrm{D}$ & Yes & Bowdler (1995) \\
\hline Disaster Bay middens $(\operatorname{Tr} 1,2 \mathrm{~A})$ & 1989 & 10 & $\mathrm{D}$ & Yes & Colley (1997) \\
\hline Disaster Bay middens (Tr 2) & 1989 & 5,1 & $\mathrm{D} / \mathrm{W}$ & Yes & Colley (1997) \\
\hline Garnawala 1 and 2 & 1990 & 3 & $\mathrm{D}$ & No & David et al. (1995) \\
\hline Mackintosh 90/1 & 1991 & $7 / 3 / 1$ & $\mathrm{~W}$ & Yes & Stern and Marshall (1993) \\
\hline Montebello Is: 3 caves & 1992 & $6 / 3$ & $\mathrm{D}$ & Yes & Veth (1993) \\
\hline Carpenter's Gap 1 & 1993 & $?$ & - & Yes & O’Connor (1995) \\
\hline Tunnel Cave & 1993 & $5 / 3$ & $? \mathrm{D}$ & Yes & Dortch (2004) \\
\hline Windjana Gorge WT shelter & 1994 & $6 / 3$ & ?D & Yes & O'Connor et al. (2008) \\
\hline Serpent's Glen Rockshelter & 1995 & $5 / 2$ & $\mathrm{D}$ & Yes & O’Connor et al. (1998) \\
\hline Mimbi: Japi, Riwi & 1999 & $5 / 2$ & $? \mathrm{D}$ & Yes & Balme (2000) \\
\hline Otterbourne Island 4 & 2002 & 2.1 & $\mathrm{D} / \mathrm{W}$ & Yes & McNiven et al. (2014) \\
\hline Bunnengalla 1 & 2004 & $4 / 2$ & $\mathrm{D}$ & Yes & Slack et al. (2005) \\
\hline Bush Turkey 3 & 2005 & 1 & $\mathrm{~W}$ & No & Veth et al. (2008) \\
\hline Murray River middens & 2007 & $5 / 3$ & $?$ & Yes & Disspain et al. (2012) \\
\hline Djadjiling rockshelter & 2007 & $6 / 3$ & $? \mathrm{D}$ & Yes & Law et al. (2010) \\
\hline Boodie Cave, pit A107 & 2013 & $4 / 2 / 1$ & $\mathrm{~W}$ & Yes & Veth et al. (2014) \\
\hline
\end{tabular}


introduced by taphonomic processes, can be confidently identified. Some new collections, such as that from the A107 excavation in Boodie Cave, made to higher standards, provide the opportunity to prove that such an approach is worth the time and effort to pursue. Fine screen residues take much more time to generate (e.g. Meighan 1969), as well as to sort and identify the contained fauna (Ball and Bobrowsky 1987); and for these reasons may not be worked up immediately but stored, e.g. as an 'insurance policy' (Payne 1972), or even as potential future teaching materials (R.E. Morlan quoted by Ball and Bobrowsky 1987). The investigation by Lyman (2012) of 40-year-old material shows just what a valuable resource they can be. Storage of excavated archaeological materials is not without financial costs: decisions on where materials will be stored often require detailed consultations with traditional owners of the sites, and archival quality storage containers are expensive. In Australia such costs are frequently borne by the state museums, whose functional budgets as a proportion of their state's revenues have been declining for decades. As part of the methodological change towards more complete recovery and analysis, archaeologists need to take into account the costs of curation and long term storage of excavated materials when planning projects.

Our suggestion that wet screening with immersed sieves lets through more fine particles than sprayed water wet sieving or dry screening, requires more detailed experimental investigation to confirm it. There is also a need for investigation of the effects of differential recovery on the marsupial and small lizard components of Australian Quaternary assemblages, neither of which were considered in our study.

\section{ACKNOWLEDGEMENTS}

We thank Tiina Manne and Marshal Weisler for organizing an excellent zooarchaeology symposium at the University of Queensland in May 2014, at which a preliminary version of this study was presented. Tiina Manne and Carly Monks provided very helpful and constructive comments on drafts of this paper, and assisted with literature access. Referees Lee Lyman and Gavin Prideaux both delivered very constructive and insightful criticisms which enabled us to greatly improve the paper. Peter Veth kindly permitted us to use crucial unpublished faunal data from the Barrow Island archaeological project. Moya Smith lent us a $3 \mathrm{~mm}$ archaeological sieve and advised on costs of storage of excavated materials. Our research was carried out in the Department of Earth and Planetary Sciences of the Western Australian Museum; we thank Mikael Siversson, Curator of Palaeontology, for access to the collection and use of facilities, including loan of fine sieves. Darren Brooks provided a survey and other information on Quarry Cave.

\section{REFERENCES}

Andrews, P. (1990). Owls, caves and fossils: predation, preservation and accumulation of small mammal bones in caves, with an analysis of the Pleistocene cave faunas from Westbury-sub-Mendip, Somerset, UK. Natural History Museum Publications: London.

Avery, D.M. (1982). Micromammals as palaeoenvironmental indicators and an interpretation of the late Quaternary in the southern Cape Province, South Africa. Annals of the South African Museum 85: 183-374.

Ball, B.F. and Bobrowsky, P.T. (1987). Cost effectiveness and time management evaluation of intensive recovery techniques. Canadian Journal of Archaeology 11: 75-97.

Balme, J. (2000). Excavations revealing 40,000 years of occupation at Mimbi Caves, south central Kimberley, Western Australia. Australian Archaeology No. 51: 1-5.

Balme, J.M., Merrilees, D. and Porter, J.K. (1978). Late Quaternary mammal remains, spanning about 30000 years, from excavations in Devil's Lair, Western Australia. Journal of the Royal Society of Western Australia 61: 33-65.

Bastian, L. (1964). Morphology and development of caves in the southwest of Western Australia. Helictite 2: 105-119.

Baynes, A. (1982). Dasyurids (Marsupialia) in late Quaternary communities in southwestern Australia. In: Archer, M. (ed.), Carnivorous marsupials: 503-510. Royal Zoological Society of New South Wales: Mosman.

Baynes, A. (1989). Clines and climate: reading rainfall from rats? In: Donnelly, T.H and Wasson, R.J. (eds), CLIMANZ 3. Proceedings of the third symposium of the late Quaternary climatic history of Australasia (Melbourne University 2829 Nov 1987): 86-90. CSIRO Division of Water Resources: Canberra.

Baynes, A. and Baird, R.F. (1992). The original mammal fauna and some information on the original bird fauna of Uluru National Park, Northern Territory. The Rangeland Journal 14: $92-106$.

Baynes, A. and Johnson, K.A. (1996). The contributions of the Horn Expedition and cave deposits to knowledge of the original mammal fauna of central Australia. In: Morton, S.R. and Mulvaney, D.J. (eds), Exploring central Australia: society, the environment and the 1894 Horn Expedition: 168-186. Surrey Beatty \& Sons: Chipping Norton.

Baynes, A. and McDowell, M.C. (2010). The original mammal fauna of the Pilbara biogeographic region of north-western Australia. Records of the Western Australian Museum, Supplement 78(1): 285-297.

Bilney, R.J., Cooke, R. and White, J.G. (2010). Underestimated and severe: small mammal decline from the forests of southeastern Australia since European settlement, as revealed by a top-order predator. Biological Conservation 143: 52-59.

Blois, J.L., McGuire, J.L. and Hadly, E.A. (2010). Small mammal diversity loss in response to late-Pleistocene climatic change. Nature 465: 771-774.

Bowdler, S. (1995). The excavation of two small rockshelters at Monkey Mia, Shark Bay, Western Australia. Australian Archaeology No. 40: 1-13.

Braithwaite, R.W. and Covacevich, J. (1995). Delicate Mouse Pseudomys delicatulus (Gould, 1842). In: Strahan, R. (ed.). The mammals of Australia, revised edition: 592-593. Reed Books: Chatswood.

Casteel, R.W. (1972). Some biases in the recovery of archaeological faunal remains. Proceedings of the Prehistoric Society 38: 382-388.

Colley, S.M. (1997). A pre- and post-contact Aboriginal shell midden at Disaster Bay, New South Wales south coast. Australian Archaeology No. 45: 1-19. 
Cook, M.J. (1965). The Anatomy of the Laboratory Mouse. Academic Press. http://www.informatics.jax.org/cookbook/ chapters/contents2.shtml

David, B., Collins, J., Barker, B., Flood, J. and Gunn, R. (1995). Archaeological research in Wardaman country, Northern Territory: the Lightning Brothers Project 1990-91 field seasons. Australian Archaeology No. 41: 1-8.

Disspain, M.C.F., Wilson, C.J. and Gillanders, B.M. (2012). Morphological and chemical analysis of archaeological fish otoliths from the lower Murray River, South Australia. Archaeology in Oceania 47: 141-150.

Dortch, J. (2004). Palaeo-environmental change and the persistence of human occupation in south-western Australian forests. British Archaeological Reports International Series No. 1288: i-xi, 1-226.

Fernández-Jalvo, Y., Andrews, P., Sevilla, P. and Requejo, V. (2014). Digestion versus abrasion features in rodent bones. Lethaia 47: 323-336.

Gargett, R.H. and Vale, D. (2005). There's something fishy going on around here. Journal of Archaeological Science 32: 647-652.

Garvey, J.M. (2006). Preliminary zooarchaeological interpretations from Kutikina Cave, south-west Tasmania. Australian Aboriginal Studies 2006(1): 57-62.

Gifford, E.W. (1916). Composition of California shellmounds. University of California Publications in American Archaeology and Ethnology 12: 1-29.

Gifford-Gonzalez, D.P., Damrosch, D.B., Damrosch, D.R., Pryor, J. and Thunen, R.L. (1985). The third dimension in site structure: an experiment in trampling and vertical dispersal. American Antiquity 50: 803-818.

Gordon, E.A. (1993). Screen size and differential faunal recovery: a Hawaiian example. Journal of Field Archaeology 20: 453-460.

Gotelli, M.J. and Colwell, R.K. (2001). Quantifying biodiversity: procedures and pitfalls in the measurement and comparison of species richness. Ecology Letters 4: 379-391.

James, S.R. (1997). Methodological issues concerning screen size recovery rates and their effects on archaeofaunal interpretations. Journal of Archaeological Science 24: 385-397.

Law, W.B., Cropper, D.N. and Petchey, F. (2010). Djadjiling rockshelter: $35,000{ }^{14} \mathrm{C}$ years of Aboriginal occupation in the Pilbara, Western Australia. Australian Archaeology No. 70: 68-71.

Lundelius, E.L. Jr and Turnbull, W.D. (1973). The mammalian fauna of Madura Cave, Western Australia. Part I. Fieldiana Geology 35: 1-35.

Lyman, R.L. (2012). The influence of screen mesh size, and size and shape of rodent teeth on recovery. Journal of Archaeological Science 39: 1854-1861.

Lyman, R.L. and Ames, K.M. (2007). On the use of speciesarea curves to detect the effects of sample size. Journal of Archaeological Science 34: 1985-1990.

Magurran, A.E. and Henderson, P.A. (2003). Explaining the excess of rare species in natural abundance distributions. Nature 422: 714-716.

Manne, T. and Veth, P.M. (2015). Late Pleistocene and early Holocene exploitation of estuarine communities in northwestern Australia. Quaternary International 385: $112-123$.

May, R.M. (1975). Patterns of species abundance and diversity. In: Cody, M.L. and Diamond, J.M. (eds), Ecology and evolution of communities: 81-120. Belknap Press: Cambridge, Massachusetts.

McDowell, M.C. (2014). Holocene vertebrate fossils aid the management and restoration of Australian ecosystems. Ecological Management \& Restoration 15: 58-63.

McNiven, I.J., De Maria, N., Weisler, M. and Lewis, T. (2014). Darumbal voyaging: intensifying use of central Queensland's Shoalwater Bay islands over the past 5000 years. Archaeology in Oceania 49: 2-42.

Meighan C.W. (1969). Molluscs as food remains in archaeological sites. In: Brothwell, D. and Higgs, E. (eds). Science in archaeology: a survey of progress and research, second edition: 415-422. Thames and Hudson: London.

Monks, C., Thorn, K., Baynes, A. and Dortch J. (2014). An archaeological and palaeoecological investigation of Caladenia Cave, northern Swan Coastal Plain, Western Australia. Paper presented in the symposium "North to south: exploring zooarchaeological research from across Australia' at the 37th annual conference of the Australian Archaeological Association, Cairns, December 2014.

Morlan, R.E. (1994). Rodent bones in archaeological sites. Canadian Journal of Archaeology 18: 135-142.

Muckle, R.J. (1994). Differential recovery of mollusk shell from archaeological sites. Journal of Field Archaeology 21: $129-131$.

Nagaoka, L. (1994). Differential recovery of Pacific island fish remains: evidence from Moturakau rockshelter, Aitutaki, Cook Islands. Asian Perspectives 33: 1-17.

Nagaoka, L. (2005). Differential recovery of Pacific island fish remains. Journal of Archaeological Science 32: 941-955.

Noe-Nygaard, N. (1977). Butchering and marrow fracturing as a taphonomic factor in archaeological deposits. Paleobiology 3: $218-237$.

O’Connor, S. (1995). Carpenter's Gap Rockshelter 1: 40,000 years of Aboriginal occupation in the Napier Ranges, Kimberley, WA. Australian Archaeology No. 40: 58-59.

O'Connor, S., Aplin, K. and Collins, S. (2008). A small salvage excavation in Windjana Gorge, Kimberley, Western Australia. Archaeology in Oceania 43: 75-81.

O'Connor, S., Veth, P. and Campbell, C. (1998). Serpent's Glen Rockshelter: report of the first Pleistocene-aged occupation sequence from the western Desert. Australian Archaeology No. 46: $12-22$.

Payne, S. (1972). Partial recovery and sample bias: the results of some sieving experiments. In: Higgs, E.S. (ed.), Papers in economic prehistory: 49-64. Cambridge University Press: Cambridge.

Piper, C.J. (2014). Palaeoecology of fossil mammals from an archaeological excavation in Morgan's Cave, Montebello Islands, north-western Australia, pp. 1-103. Unpublished Honours thesis, Faculty of Natural and Agricultural Science, The University of Western Australia: Perth.

Reeves, J.M., Bostock, H.C., Ayliffe, L.K., Barrows, T.T., De Deckker, P., Devriendt, L.S., Dunbar, G.B., Drysdale, R.N., Fitzsimmons, K.E., Gagan, M.K., Griffiths, M.L., Haberle, S.G., Jansen, J.D., Krause, C., Lewis, S., McGregor, H.V., Mooney, S.D., Moss, P., Nanson, G.C., Purcell, A. and van der Kaars, S. (2013). Palaeoenvironmental change in tropical Australasia over the last 30,000 years - a synthesis by the OZ-INTIMATE group. Quaternary Science Reviews 74: $97-114$

Sgarbi, L.F. and Melo, A.S. (2018). You don't belong here: explaining the excess of rare species in terms of habitat, space and time. Oikos 127: 497-506. 
Shaffer, B.S. (1992). Quarter-inch screening: understanding biases in recovery of vertebrate faunal remains. American Antiquity 57: 129-136.

Shaffer, B.S. and Sanchez, J.L.J. (1994). Comparison of 1/8"and 1/4"-mesh recovery of controlled samples of small-tomedium-sized mammals. American Antiquity 59: 525-530.

Simpson, E.H. (1949). Measurement of diversity. Nature 163: 688.

Slack, M., Fullagar, R., Border, A., Diamond, J. and Field, J. (2005). Late Holocene occupation at Bunnengalla 1, Musselbrook Creek, northwest Queensland. Australian Archaeology No. 60: 54-58.

Stahl, P.W. (1996). The recovery and interpretation of microvertebrate bone assemblages from archaeological contexts. Journal of Archaeological Method and Theory 3: $31-75$.

Stern, N. and Marshall, B. (1993). Excavations at Mackintosh 90/1 in western Tasmania: a discussion of stratigraphy, chronology and site formation. Archaeology in Oceania 28: 8-17.

Stewart, K.M. and Wigen, R.J. (2003). Screen size and the need for reinterpretation: a case study from the northwest coast. Bulletin of the Florida Museum of Natural History 44: 27-34.

Strahan, R., ed. (1995). The mammals of Australia. Reed Books: Chatswood.

Thomas, D.H. (1969). Great Basin hunting patterns: a quantitative method for treating faunal remains. American Antiquity 34: 392-401.

Thorn, K.M., Roe, R., Baynes, A., Hart, R.P., Lance, K.A., Merrilees, D., Porter, J.K. and Sofoulis, S. (2017). Fossil mammals of Caladenia Cave, northern Swan Coastal Plain, south-western Australia. Records of the Western Australian Museum 32: 217-236.

Vale, D. and Gargett, R.H. (2002). Size matters: 3-mm sieves do not increase richness in a fishbone assemblage from Arrawarra 1, an Aboriginal Australian shell midden on the mid-north coast of New South Wales, Australia. Journal of Archaeological Science 29: 57-63.

Veth, P. (1993). The Aboriginal occupation of the Montebello Islands, northwest Australia. Australian Aboriginal Studies 1993(2): 39-50.

Veth, P., Aplin, K., Wallis, L., Manne, T., Pulsford, T., White, E. and Chappell, A. (2007). The archaeology of Montebello Islands, north-west Australia: late Quaternary foragers on an arid coastline. British Archaeological Reports International Series No. 1668: i-iii, 1-84.

Veth, P., Ditchfield, K. and Hook, F. (2014). Maritime deserts of the Australian northwest. Australian Archaeology No. 79: 156-166.

Veth, P., McDonald, J. and White, B. (2008). Dating of Bush Turkey Rockshelter 3 in the Calvert Ranges establishes early Holocene occupation of the Little Sandy Desert, Western Australia. Australian Archaeology No. 66: 33-44.

Veth, P., Ward, I., Manne, T., Ulm, S., Ditchfield, K., Dortch, J., Hook, F., Petchey, F., Hogg, A., Questiaux, D., Demuro, M., Arnold, L., Spooner, N., Levchenko, V., Skippington, J., Byrne, C., Basgall, M., Zeanah, D., Belton, D., Helmholz, P., Bajkan, S., Bailey, R., Placzek, C. and Kendrick, P. (2017). Early human occupation of a maritime desert, Barrow Island, north-west Australia. Quaternary Science Reviews 168: 19-29.

Woinarski, J.C.Z., Burbidge, A.A. and Harrison, P.L. (2015). Ongoing unraveling of a continental fauna: decline and extinction of Australian mammals since European settlement. Proceedings of the National Academy of Sciences of the United States of America 112: 4531-4540.

Wolff, R.G. (1975). Sampling and sample size in ecological analyses of fossil mammals. Paleobiology 1: 195-204.

Ziegler, A.C. (1965). The role of faunal remains in archaeological investigations. Sacramento Anthropological Society Papers No. 3: 47-75.

MANUSCRIPT RECEIVED 15 APRIL 2018; ACCEPTED 18 JULY 2019. 


\section{APPENDIX}

TABLE A1. Categories of completeness used in recording numbers of specimens listed in Tables A2 and A7.

Category

1 Complete or nearly intact jaws with first, second and third molars present.

2 Less complete jaws, with first molar, plus second and third molars, or their empty alveoli.

3 More damaged jaws with first molar and only second molar or its alveolus.

$4 \quad$ Just first molars in bone fragments.

$5 \quad$ Isolated first molars.

TABLE A2. Raw numbers of murid specimens (left and right jaws combined) from Quarry Cave, retained on sieves with three different mesh apertures in each of five categories of completeness, ranging from complete jaws with all molars present (1) to isolated first molars (5) (details in Table A1). Species are listed from smallest at the beginning to largest at the end.

$\begin{array}{llllll}1 & 2 & 3 & 4 & 5 & \text { Totals }\end{array}$

\section{Pseudomys hermannsburgensis}

Retained on $3 \mathrm{~mm}$ sieve

$\begin{array}{lllllll}\text { Upper } & 30 & 22 & 7 & 19 & 7 & 85\end{array}$

$\begin{array}{lllllll}\text { Lower } & 46 & 29 & 12 & 5 & 7 & 99\end{array}$

$\begin{array}{lllllll}\text { Upper and lower combined } & 76 & 51 & 19 & 24 & 14 & 184\end{array}$

Not retained on $3 \mathrm{~mm}$ but retained on $1.63 \mathrm{~mm}$ sieve

$\begin{array}{lllllll}\text { Upper } & 3 & 5 & 7 & 21 & 3 & 39\end{array}$

$\begin{array}{lllllll}\text { Lower } & 0 & 2 & 7 & 17 & 5 & 32\end{array}$

$\begin{array}{lllllll}\text { Upper and lower combined } & 3 & 7 & 14 & 38 & 8 & 71\end{array}$

Not retained on $1.63 \mathrm{~mm}$ but retained on $0.71 \mathrm{~mm}$ sieve

$\begin{array}{lllllll}\text { Upper } & 0 & 0 & 2 & 0 & 101 & 103\end{array}$

$\begin{array}{lllllll}\text { Lower } & 0 & 0 & 0 & 1 & 68 & 69\end{array}$

$\begin{array}{lllllll}\text { Upper and lower combined } & 0 & 0 & 2 & 1 & 169 & 172\end{array}$

Species total

\section{Pseudomys chapmani}

Retained on $3 \mathrm{~mm}$ sieve

$\begin{array}{lllllll}\text { Upper } & 6 & 4 & 0 & 2 & 2 & 14\end{array}$

$\begin{array}{lllllll}\text { Lower } & 20 & 10 & 1 & 1 & 2 & 34\end{array}$

$\begin{array}{llllllll}\text { Upper and lower combined } & 26 & 14 & 1 & 3 & 4 & 48\end{array}$

Not retained on $3 \mathrm{~mm}$ but retained on $1.63 \mathrm{~mm}$ sieve

$\begin{array}{llllllll}\text { Upper } & 0 & 1 & 1 & 1 & 0 & 3\end{array}$

$\begin{array}{lllllll}\text { Lower } & 0 & 0 & 2 & 1 & 3 & 6\end{array}$

$\begin{array}{lllllll}\text { Upper and lower combined } & 0 & 1 & 3 & 2 & 3 & 9\end{array}$

Not retained on $1.63 \mathrm{~mm}$ but retained on $0.71 \mathrm{~mm}$ sieve

$\begin{array}{lllllll}\text { Upper } & 0 & 0 & 0 & 0 & 41 & 41\end{array}$

$\begin{array}{lllllll}\text { Lower } & 0 & 0 & 0 & 0 & 31 & 31\end{array}$

$\begin{array}{lllllll}\text { Upper and lower combined } & 0 & 0 & 0 & 0 & 72 & 72\end{array}$

Species total

\section{Leggadina sp. cf. L. lakedownensis}

Retained on $3 \mathrm{~mm}$ sieve

$\begin{array}{lrrrrrr}\text { Upper } & 8 & 5 & 2 & 3 & 1 & 19 \\ \text { Lower } & 8 & 3 & 2 & 3 & 2 & 18 \\ \text { Upper and lower combined } & 16 & 8 & 4 & 6 & 3 & 37\end{array}$

Not retained on $3 \mathrm{~mm}$ but retained on $1.63 \mathrm{~mm}$ sieve

Upper

Lower

$\begin{array}{lllll}0 & 0 & 1 & 1 & 2\end{array}$

Upper and lower combined $\begin{array}{llllll}1 & 2 & 3 & 4 & 5 & \text { Totals }\end{array}$

Not retained on $1.63 \mathrm{~mm}$ but retained on $0.71 \mathrm{~mm}$ sieve

Upper

$\begin{array}{llllll}0 & 0 & 0 & 0 & 8 & 8\end{array}$

Lower

$\begin{array}{llllll}0 & 0 & 0 & 0 & 7 & 7\end{array}$

$\begin{array}{lllllll}\text { Upper and lower combined } & 0 & 0 & 0 & 0 & 15 & 15\end{array}$

Species total

Notomys alexis

Retained on $3 \mathrm{~mm}$ sieve

$\begin{array}{lllllll}\text { Upper } & 2 & 4 & 0 & 1 & 12 & 19\end{array}$

$\begin{array}{lllllll}\text { Lower } & 11 & 3 & 5 & 4 & 6 & 29\end{array}$

$\begin{array}{lllllll}\text { Upper and lower combined } & 13 & 7 & 5 & 5 & 18 & 48\end{array}$

Not retained on $3 \mathrm{~mm}$ but retained on $1.63 \mathrm{~mm}$ sieve

$\begin{array}{lllllll}\text { Upper } & 0 & 0 & 0 & 0 & 43 & 43\end{array}$

$\begin{array}{lllllll}\text { Lower } & 0 & 0 & 0 & 0 & 42 & 42\end{array}$

$\begin{array}{lllllll}\text { Upper and lower combined } & 0 & 0 & 0 & 0 & 85 & 85\end{array}$

Not retained on $1.63 \mathrm{~mm}$ but retained on $0.71 \mathrm{~mm}$ sieve

$\begin{array}{lllllll}\text { Upper } & 0 & 0 & 0 & 0 & 2 & 2\end{array}$

$\begin{array}{lllllll}\text { Lower } & 0 & 0 & 0 & 0 & 3 & 3\end{array}$

Upper and lower combined $\quad \begin{array}{llllll}0 & 0 & 0 & 0 & 5 & 5\end{array}$

Species total

\section{Pseudomys desertor}

Retained on $3 \mathrm{~mm}$ sieve

$\begin{array}{lllllll}\text { Upper } & 1 & 1 & 0 & 0 & 0 & 2\end{array}$

$\begin{array}{lllllll}\text { Lower } & 9 & 2 & 2 & 0 & 2 & 15\end{array}$

$\begin{array}{lllllll}\text { Upper and lower combined } & 10 & 3 & 2 & 0 & 2 & 17\end{array}$

Not retained on $3 \mathrm{~mm}$ but retained on $1.63 \mathrm{~mm}$ sieve

$\begin{array}{lllllll}\text { Upper } & 0 & 0 & 0 & 0 & 23 & 23\end{array}$

$\begin{array}{lllllll}\text { Lower } & 0 & 0 & 0 & 0 & 12 & 12\end{array}$

Upper and lower combined $\quad \begin{array}{llllll}0 & 0 & 0 & 0 & 35 & 35\end{array}$

Not retained on $1.63 \mathrm{~mm}$ but retained on $0.71 \mathrm{~mm}$ sieve

$\begin{array}{lllllll}\text { Upper } & 0 & 0 & 0 & 0 & 3 & 3\end{array}$

$\begin{array}{lllllll}\text { Lower } & 0 & 0 & 0 & 0 & 2 & 2\end{array}$

Upper and lower combined $\quad \begin{array}{llllll}0 & 0 & 0 & 0 & 5 & 5\end{array}$

$\begin{array}{ll}\text { Species total } & 57\end{array}$ 
$\begin{array}{llllll}1 & 2 & 3 & 4 & 5 & \text { Totals }\end{array}$

\section{Pseudomys fieldi}

Retained on $3 \mathrm{~mm}$ sieve

$\begin{array}{lrrrrrr}\text { Upper } & 2 & 3 & 1 & 0 & 5 & 11 \\ \text { Lower } & 8 & 1 & 0 & 1 & 0 & 10 \\ \text { Upper and lower combined } & 10 & 4 & 1 & 1 & 5 & 21\end{array}$

Not retained on $3 \mathrm{~mm}$ but retained on $1.63 \mathrm{~mm}$ sieve

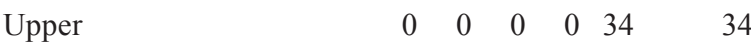

Lower $\quad 0 \begin{array}{llllll}0 & 0 & 0 & 0 & 12 & 12\end{array}$

Upper and lower combined $\quad \begin{array}{llllll}0 & 0 & 0 & 0 & 46 & 46\end{array}$

Not retained on $1.63 \mathrm{~mm}$ but retained on $0.71 \mathrm{~mm}$ sieve

Upper $\quad 0 \begin{array}{llllll}0 & 0 & 0 & 2 & 2\end{array}$

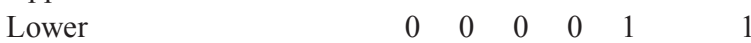

Upper and lower combined $\quad \begin{array}{lllllll}0 & 0 & 0 & 0 & 3 & 3\end{array}$

Species total

\section{Pseudomys nanus}

Retained on $3 \mathrm{~mm}$ sieve

$\begin{array}{llllllll}\text { Upper } & 14 & 3 & 4 & 1 & 10 & 32\end{array}$

$\begin{array}{lllllll}\text { Lower } & 24 & 12 & 2 & 2 & 7 & 47\end{array}$

$\begin{array}{lllllll}\text { Upper and lower combined } & 38 & 15 & 6 & 3 & 17 & 79\end{array}$

Not retained on $3 \mathrm{~mm}$ but retained on $1.63 \mathrm{~mm}$ sieve

$\begin{array}{llllllll}\text { Upper } & 0 & 0 & 2 & 0 & 81 & 83\end{array}$

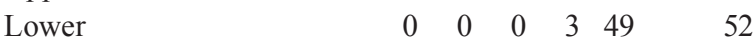

$\begin{array}{lllllll}\text { Upper and lower combined } & 0 & 0 & 2 & 3 & 130 & 135\end{array}$

Not retained on $1.63 \mathrm{~mm}$ but retained on $0.71 \mathrm{~mm}$ sieve

Upper $\quad \begin{array}{lllllll}0 & 0 & 0 & 0 & 24 & 24\end{array}$

Lower $\quad \begin{array}{llllll}0 & 0 & 0 & 0 & 25 & 25\end{array}$

Upper and lower combined $\quad 0 \quad 0 \quad 0 \quad 000049$

Species total

263

\section{Rattus tunneyi}

Retained on $3 \mathrm{~mm}$ sieve

$\begin{array}{lrrrrrr}\text { Upper } & 11 & 6 & 2 & 2 & 34 & 55 \\ \text { Lower } & 49 & 1 & 1 & 3 & 10 & 64 \\ \text { Upper and lower combined } & 60 & 7 & 3 & 5 & 44 & 119 \\ \text { Not retained on 3 mm but retained on } & 1.63 & \text { mm sieve } & \\ \text { Upper } & 0 & 0 & 0 & 0 & 45 & 45 \\ \text { Lower } & 0 & 0 & 0 & 0 & 37 & 37 \\ \text { Upper and lower combined } & 0 & 0 & 0 & 0 & 82 & 82\end{array}$

Not retained on $1.63 \mathrm{~mm}$ but retained on $0.71 \mathrm{~mm}$ sieve

Upper

Lower

$\begin{array}{lllll}0 & 0 & 0 & 0 & 0\end{array}$

$\begin{array}{ccccc}0 & 0 & 0 & 0 & 0\end{array}$

Upper and lower combined $\quad \begin{array}{llllll}0 & 0 & 0 & 0 & 0\end{array}$

Species total

\section{Notomys longicaudatus}

Retained on $3 \mathrm{~mm}$ sieve

$\begin{array}{lrrrrrr}\text { Upper } & 15 & 5 & 2 & 2 & 45 & 69 \\ \text { Lower } & 46 & 7 & 0 & 4 & 31 & 88 \\ \text { Upper and lower combined } & 61 & 12 & 2 & 6 & 76 & 157\end{array}$

\section{$\begin{array}{llllll}1 & 2 & 3 & 4 & 5 & \text { Totals }\end{array}$}

Not retained on $3 \mathrm{~mm}$ but retained on $1.63 \mathrm{~mm}$ sieve

Upper

Lower

$\begin{array}{lllllll}0 & 0 & 0 & 0 & 14 & 14\end{array}$

Upper and lower combined

$\begin{array}{lllllll}0 & 0 & 0 & 0 & 34 & 34\end{array}$

Not retained on $1.63 \mathrm{~mm}$ but retained on $0.71 \mathrm{~mm}$ sieve

Upper

Lower

$\begin{array}{lllll}0 & 0 & 0 & 0 & 0\end{array}$

Upper and lower combined

$\begin{array}{lllll}0 & 0 & 0 & 0 & 0\end{array}$

Species total

\section{Zyzomys pedunculatus}

Retained on $3 \mathrm{~mm}$ sieve

Upper

Lower

$\begin{array}{llllll}1 & 1 & 0 & 0 & 6 & 8\end{array}$

$\begin{array}{llllll}1 & 0 & 0 & 0 & 7 & 8\end{array}$

$\begin{array}{lllllll}\text { Upper and lower combined } & 2 & 1 & 0 & 0 & 13 & 16\end{array}$

Not retained on $3 \mathrm{~mm}$ but retained on $1.63 \mathrm{~mm}$ sieve

Upper

Lower

$\begin{array}{llllll}0 & 0 & 0 & 0 & 4 & 4\end{array}$

$\begin{array}{llllll}0 & 0 & 0 & 0 & 3 & 3\end{array}$

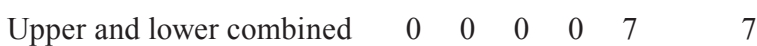

Not retained on $1.63 \mathrm{~mm}$ but retained on $0.71 \mathrm{~mm}$ sieve

Upper

Lower

$\begin{array}{llllll}0 & 0 & 0 & 0 & 0 & 0\end{array}$

Upper and lower combined $\quad 0 \quad 0 \quad 0 \quad 0 \quad 0000$

Species total

\section{Leporillus conditor}

Retained on $3 \mathrm{~mm}$ sieve

$\begin{array}{llllllll}\text { Upper } & 2 & 0 & 0 & 0 & 1 & 3\end{array}$

Lower $\quad 0 \begin{array}{llllll}0 & 0 & 0 & 0 & 0\end{array}$

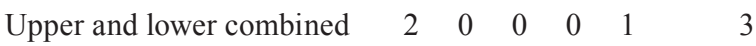

Not retained on $3 \mathrm{~mm}$ but retained on $1.63 \mathrm{~mm}$ sieve

Upper $\quad 0 \begin{array}{llllll}0 & 0 & 0 & 0 & 0\end{array}$

Lower $\quad 0 \begin{array}{llllll}0 & 0 & 0 & 0 & 0\end{array}$

Upper and lower combined $\quad 0 \quad 0 \quad 0 \quad 0 \quad 0000$

Not retained on $1.63 \mathrm{~mm}$ but retained on $0.71 \mathrm{~mm}$ sieve

Upper

Lower

$\begin{array}{llllll}0 & 0 & 0 & 0 & 0 & 0\end{array}$

Upper and lower combined $\quad 0 \quad 0 \quad 0 \quad 0 \quad 0000$

Species total

\section{Mesembriomys macrurus}

Retained on $3 \mathrm{~mm}$ sieve

Upper $\quad 0 \begin{array}{llllll}0 & 0 & 0 & 0 & 0 & 0\end{array}$

Lower $\quad 0 \begin{array}{llllll}0 & 0 & 0 & 2 & 2\end{array}$

Upper and lower combined $\quad \begin{array}{llllll}0 & 0 & 0 & 0 & 2 & 2\end{array}$

Not retained on $3 \mathrm{~mm}$ but retained on $1.63 \mathrm{~mm}$ sieve

Upper $\quad 0 \begin{array}{lllllll}0 & 0 & 0 & 0 & 0\end{array}$

Lower $\quad 0 \begin{array}{llllll}0 & 0 & 0 & 1 & 1\end{array}$

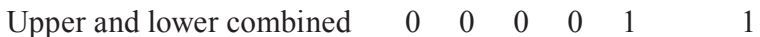

Not retained on $1.63 \mathrm{~mm}$ but retained on $0.71 \mathrm{~mm}$ sieve

Upper

$\begin{array}{llllll}0 & 0 & 0 & 0 & 0 & 0\end{array}$

Lower

$\begin{array}{llllll}0 & 0 & 0 & 0 & 0 & 0\end{array}$

Upper and lower combined $\quad \begin{array}{lllllll}0 & 0 & 0 & 0 & 0 & 0\end{array}$

Species total 
TABLE A3. Calculations of $X^{2}$ values for chi-square tests of the statistical significance of the bias introduced by differential recovery into the relative abundances of species retained by the $3 \mathrm{~mm}$ sieve alone, and $3 \mathrm{~mm}+1.63 \mathrm{~mm}$ sieves, as reported in Table 2. Obs and $O=$ Observed; Exp and $E=$ Expected. Most calculated numbers rounded for presentation.

\begin{tabular}{|c|c|c|c|c|c|c|c|c|c|}
\hline & $\begin{array}{r}3 \mathrm{~mm} \\
\text { sieve } \\
\text { Obs }\end{array}$ & $\begin{array}{r}1.63 \mathrm{~mm} \\
\text { sieve }\end{array}$ & $\begin{array}{r}0.71 \mathrm{~mm} \\
\text { sieve }\end{array}$ & $\begin{array}{r}\text { Sample } \\
\text { Total }\end{array}$ & Total $p i$ & $\begin{array}{r}3 \mathrm{~mm} \\
\text { sieve } \\
\text { Exp }\end{array}$ & $\begin{array}{r}3 \mathrm{~mm} \\
\text { seive } \\
O-E\end{array}$ & $(O-E)^{2}$ & $(O-E)^{2} / E$ \\
\hline P. herm. & 184 & 71 & 172 & 427 & 0.2694 & 196.93 & -12.932 & 167.2330 & 0.8492 \\
\hline P. chap. & 48 & 9 & 72 & 129 & 0.0814 & 59.49 & -11.495 & 132.1267 & 2.2208 \\
\hline Leg. & 37 & 14 & 15 & 66 & 0.0416 & 30.44 & 6.561 & 43.0452 & 1.4141 \\
\hline$N$. alexis & 48 & 85 & 5 & 138 & 0.0871 & 63.65 & -15.645 & 244.7793 & 3.8460 \\
\hline P. des. & 17 & 35 & 5 & 57 & 0.0360 & 26.29 & -9.288 & 86.2730 & 3.2818 \\
\hline P. fieldi & 21 & 46 & 3 & 70 & 0.0442 & 32.28 & -11.284 & 127.3267 & 3.9440 \\
\hline P. nanus & 79 & 135 & 49 & 263 & 0.1659 & 121.30 & -42.295 & 1788.8897 & 14.7482 \\
\hline R.tun. & 119 & 82 & 0 & 201 & 0.1268 & 92.70 & 26.299 & 691.6402 & 7.4610 \\
\hline N. long. & 157 & 48 & 0 & 205 & 0.1293 & 94.55 & 62.454 & 3900.5344 & 41.2555 \\
\hline Z. ped. & 16 & 7 & 0 & 23 & 0.0145 & 10.61 & 5.392 & 29.0783 & 2.7413 \\
\hline L. cond. & 3 & 0 & 0 & 3 & 0.0019 & 1.384 & 1.616 & 2.6128 & 1.8884 \\
\hline M. mac. & 2 & 1 & 0 & 3 & 0.0019 & 1.384 & 0.616 & 0.3799 & 0.2746 \\
\hline Totals & 731 & 533 & 321 & 1585 & 1 & 731 & & & 83.9249 \\
\hline$X^{2}$ & & & & & & & & & 83.925 \\
\hline$d$ of $f$ & & & & & & & & & 11 \\
\hline$P$ & & & & & & & & & $<0.001$ \\
\hline
\end{tabular}

\begin{tabular}{|c|c|c|c|c|c|c|c|c|}
\hline & $\begin{array}{r}3 \mathrm{~mm}+ \\
1.63 \mathrm{~mm} \\
\text { sieves } \\
\text { Obs }\end{array}$ & $\begin{array}{r}0.71 \mathrm{~mm} \\
\text { sieve }\end{array}$ & $\begin{array}{r}\text { Sample } \\
\text { Total }\end{array}$ & Total pi & $\begin{array}{r}3 \mathrm{~mm}+ \\
1.63 \mathrm{~mm} \\
\text { sieves } \\
\text { Exp }\end{array}$ & $\begin{array}{r}3 \mathrm{~mm}+ \\
1.63 \mathrm{~mm} \\
\text { sieves } \\
O-E\end{array}$ & $(O-E)^{2}$ & $(O-E)^{2} / E$ \\
\hline P. herm. & 255 & 172 & 427 & 0.2694 & 340.52 & -85.523 & 7314.0805 & 21.4790 \\
\hline P. chap. & 57 & 72 & 129 & 0.0814 & 102.87 & -45.874 & 2104.4650 & 20.4566 \\
\hline Leg. & 51 & 15 & 66 & 0.0416 & 52.63 & -1.633 & 2.6681 & 0.0507 \\
\hline N. alexis & 133 & 5 & 138 & 0.0871 & 110.05 & 22.948 & 526.6229 & 4.7852 \\
\hline P. des. & 52 & 5 & 57 & 0.0360 & 45.46 & 6.544 & 42.8220 & 0.9421 \\
\hline P. fieldi & 67 & 3 & 70 & 0.0442 & 55.82 & 11.177 & 124.9176 & 2.2377 \\
\hline P. nanus & 214 & 49 & 263 & 0.1659 & 209.74 & 4.264 & 18.1793 & 0.0867 \\
\hline R. tun. & 201 & 0 & 201 & 0.1268 & 160.29 & 40.707 & 1657.0807 & 10.3378 \\
\hline N. long. & 205 & 0 & 205 & 0.1293 & 163.48 & 41.517 & 1723.6904 & 10.5436 \\
\hline Z. ped. & 23 & 0 & 23 & 0.0145 & 18.34 & 4.658 & 21.6974 & 1.1829 \\
\hline L. cond. & 3 & 0 & 3 & 0.0019 & 2.392 & 0.608 & 0.3691 & 0.1543 \\
\hline M. mac. & 3 & 0 & 3 & 0.0019 & 2.392 & 0.608 & 0.3691 & 0.1543 \\
\hline Totals & 1264 & 321 & 1585 & 1 & 1264 & & & 72.4110 \\
\hline$X^{2}$ & & & & & & & & 72.411 \\
\hline$d$ of $f$ & & & & & & & & 11 \\
\hline$P$ & & & & & & & & $<0.001$ \\
\hline
\end{tabular}


TABLE A4. Criteria of first molar age classes.

Age class

1 Roots incompletely formed and open on the ends, negligible tooth wear restricted to the tips of the cusps.

2 Roots completely formed, with ends closed up to just pores, tooth wear slight to moderate but with cusps still discreet.

3 Greater tooth wear has resulted in the dentine cores of the cusps to be exposed and connected laterally across all three lophs of the first molar.

$4 \quad$ Further tooth wear has resulted in dentine cores of lophs becoming connected.

$5 \quad$ Extreme tooth wear has left just a basin of dentine with an enamel rim.

TABLE A5. Measurements and age class scores (using the criteria listed in Table A4) of isolated first molar teeth of Rattus tunneyi from Quarry Cave. $\left({ }^{*}\right)$ Includes broken M1s.

\begin{tabular}{|c|c|c|c|c|c|c|c|c|c|}
\hline $\begin{array}{l}\text { Age } \\
\text { class }\end{array}$ & $\begin{array}{l}\text { Crown } \\
\text { length } \\
(\mathrm{mm})\end{array}$ & $\begin{array}{l}\text { Crown } \\
\text { width } \\
(\mathrm{mm})\end{array}$ & $\begin{array}{l}\text { Height } \\
(\mathrm{mm})\end{array}$ & $\begin{array}{l}\text { Diagonal } \\
\text { length } \\
(\mathrm{mm})\end{array}$ & $\begin{array}{l}\text { Age } \\
\text { class }\end{array}$ & $\begin{array}{l}\text { Crown } \\
\text { length } \\
(\mathrm{mm})\end{array}$ & $\begin{array}{l}\text { Crown } \\
\text { width } \\
(\mathrm{mm})\end{array}$ & $\begin{array}{l}\text { Height } \\
(\mathrm{mm})\end{array}$ & $\begin{array}{l}\text { Diagonal } \\
\text { length } \\
(\mathrm{mm})\end{array}$ \\
\hline \multicolumn{5}{|c|}{ First upper M1s retained on $3 \mathrm{~mm}$ sieve } & \multicolumn{5}{|c|}{ First upper M1s not retained on $3 \mathrm{~mm}$ sieve } \\
\hline 3 & 3.14 & 2.20 & 2.60 & 4.86 & 3 & 3.20 & 2.06 & 2.70 & 4.82 \\
\hline 3 & 3.22 & 2.16 & 2.86 & 4.82 & 3 & 2.84 & 2.06 & 2.96 & 4.80 \\
\hline 3 & 3.34 & 2.30 & 3.04 & 4.80 & 3 & 3.32 & 1.60 & 3.10 & 4.76 \\
\hline 3 & 2.76 & 2.26 & 3.12 & 4.64 & 3 & 3.16 & 2.12 & 2.68 & 4.44 \\
\hline 3 & 3.24 & 2.16 & 2.66 & 4.56 & 3 & 2.06 & 2.10 & 2.76 & 3.94 \\
\hline 3 & 3.10 & 2.06 & 2.70 & 4.38 & 4 & 2.88 & 2.08 & 2.32 & 3.80 \\
\hline 2 & 3.36 & 2.24 & 2.54 & 5.08 & 4 & 3.10 & 2.06 & 1.66 & 3.70 \\
\hline 2 & 3.22 & 2.26 & 2.96 & 4.94 & 2 & 2.86 & 2.12 & 3.22 & 5.02 \\
\hline 2 & 3.36 & 2.26 & 2.70 & 4.86 & 2 & 3.38 & 2.22 & 3.00 & 4.90 \\
\hline 2 & 3.28 & 2.22 & 3.04 & 4.84 & 2 & 3.34 & 2.20 & 2.78 & 4.88 \\
\hline 2 & 3.08 & 2.22 & 2.76 & 4.82 & 2 & 3.34 & 2.14 & 2.84 & 4.84 \\
\hline 2 & 3.22 & 2.18 & 2.98 & 4.82 & 2 & 3.12 & 2.16 & 2.92 & 4.68 \\
\hline 2 & 3.16 & 2.20 & 2.70 & 4.82 & 2 & 3.26 & 2.06 & 2.64 & 4.64 \\
\hline 2 & 3.12 & 2.04 & 3.16 & 4.64 & 2 & 2.80 & & & 4.60 \\
\hline 2 & 3.22 & 2.20 & 2.64 & 4.62 & 2 & 2.94 & 2.04 & 2.96 & 4.48 \\
\hline 2 & 3.30 & 2.22 & 2.86 & 4.62 & 2 & 3.08 & 1.92 & 2.70 & 4.46 \\
\hline 2 & 3.14 & 2.20 & 2.70 & 4.60 & 2 & 3.40 & 2.06 & 2.62 & 4.42 \\
\hline 2 & 3.36 & 2.14 & 2.74 & 4.54 & 2 & 2.44 & & & 4.20 \\
\hline 2 & 3.24 & 2.24 & 2.78 & 4.52 & 2 & 3.06 & 2.12 & 1.74 & 3.94 \\
\hline 2 & 3.28 & 2.00 & 2.68 & 4.52 & 2 & 2.26 & 2.10 & 2.74 & 3.94 \\
\hline 2 & 3.22 & 2.00 & 2.58 & 4.48 & 2 & 3.28 & 2.20 & 2.78 & 3.84 \\
\hline 2 & 2.96 & 2.04 & 2.54 & 4.36 & 2 & 2.14 & 1.96 & 2.66 & 3.74 \\
\hline 2 & 2.18 & 2.20 & 3.12 & 3.40 & 2 & & & & 3.52 \\
\hline 1 & 3.40 & 2.14 & 2.82 & 4.68 & 1 & 3.52 & 2.06 & 2.58 & 4.49 \\
\hline 1 & 3.38 & 1.40 & 2.74 & 4.60 & 1 & 3.26 & 2.06 & 2.54 & 4.36 \\
\hline 1 & 3.30 & 2.20 & 2.68 & 4.54 & 1 & 3.44 & 2.14 & 1.94 & 4.24 \\
\hline 1 & 3.24 & 2.26 & 2.64 & 4.46 & 1 & 3.12 & 2.18 & 2.16 & 4.22 \\
\hline 1 & 3.24 & 2.08 & 2.56 & 4.36 & 1 & 3.30 & 2.14 & 2.32 & 4.20 \\
\hline 1 & 3.24 & 2.10 & 2.62 & 4.28 & 1 & 3.20 & 2.06 & 2.54 & 4.16 \\
\hline 1 & 3.20 & 2.06 & 2.52 & 4.22 & 1 & 3.06 & 2.04 & 2.24 & 4.14 \\
\hline 1 & 3.22 & 2.12 & 2.56 & 4.12 & 1 & 3.42 & 2.16 & 2.10 & 4.12 \\
\hline 1 & 3.36 & 2.24 & 2.46 & 4.12 & 1 & 3.22 & 2.16 & 2.02 & 4.04 \\
\hline 1 & 3.20 & 2.02 & 2.32 & 3.96 & 1 & 3.14 & 2.04 & 2.54 & 3.94 \\
\hline 1 & 3.06 & 2.06 & 1.76 & 3.30 & 1 & 2.96 & 1.94 & 2.10 & 3.94 \\
\hline Mean* & 3.186 & 2.138 & 2.710 & 4.505 & 1 & 3.20 & 2.12 & 1.92 & 3.94 \\
\hline Std dev ${ }^{*}$ & 0.219 & 0.156 & 0.262 & 0.387 & 1 & 3.44 & 2.28 & 1.94 & 3.78 \\
\hline Minimum* & 2.18 & 1.40 & 1.76 & 3.30 & 1 & 3.36 & 2.14 & 1.88 & 3.74 \\
\hline Maximum* & 3.40 & 2.30 & 3.16 & 5.08 & 1 & 3.36 & 2.20 & 1.84 & 3.74 \\
\hline & & & & & 1 & 3.12 & 2.08 & 2.70 & 3.70 \\
\hline
\end{tabular}




\begin{tabular}{|c|c|c|c|c|c|c|c|c|c|}
\hline $\begin{array}{l}\text { Age } \\
\text { class }\end{array}$ & $\begin{array}{l}\text { Crown } \\
\text { length } \\
(\mathrm{mm})\end{array}$ & $\begin{array}{l}\text { Crown } \\
\text { width } \\
(\mathrm{mm})\end{array}$ & $\begin{array}{l}\text { Height } \\
(\mathrm{mm})\end{array}$ & $\begin{array}{l}\text { Diagonal } \\
\text { length } \\
(\mathrm{mm})\end{array}$ & $\begin{array}{l}\text { Age } \\
\text { class }\end{array}$ & $\begin{array}{l}\text { Crown } \\
\text { length } \\
(\mathrm{mm})\end{array}$ & $\begin{array}{l}\text { Crown } \\
\text { width } \\
\text { (mm) }\end{array}$ & $\begin{array}{l}\text { Height } \\
(\mathrm{mm})\end{array}$ & $\begin{array}{l}\text { Diagonal } \\
\text { length } \\
(\mathrm{mm})\end{array}$ \\
\hline 1 & 3.48 & 2.14 & 1.64 & 3.60 & 3 & 2.54 & 1.60 & 2.16 & 3.40 \\
\hline 1 & 3.36 & 2.00 & 2.20 & 3.60 & 3 & 2.26 & 1.94 & 2.76 & 3.06 \\
\hline 1 & 3.20 & 2.20 & 1.78 & 3.58 & 2 & 2.66 & 1.86 & 3.56 & 4.34 \\
\hline 1 & 3.16 & 2.12 & 1.80 & 3.58 & 2 & 2.80 & 1.88 & 3.54 & 4.26 \\
\hline 1 & 3.26 & 2.10 & 1.84 & 3.56 & 2 & 2.90 & 1.78 & 3.38 & 4.20 \\
\hline 1 & 3.22 & 2.12 & 1.92 & 3.54 & 2 & 2.70 & 1.72 & 3.40 & 4.14 \\
\hline Mean ${ }^{*}$ & 3.115 & 2.092 & 2.389 & 4.146 & 2 & 2.76 & 1.86 & 3.30 & 4.06 \\
\hline Std dev ${ }^{*}$ & 0.336 & 0.107 & 0.450 & 0.446 & 2 & 2.54 & 1.68 & 3.14 & 4.00 \\
\hline Minimum* & 2.06 & 1.60 & 1.64 & 3.52 & 2 & 2.70 & 1.84 & 3.12 & 4.00 \\
\hline Maximum $^{*}$ & 3.52 & 2.28 & 3.22 & 5.02 & 2 & 2.68 & 1.70 & 3.16 & 3.94 \\
\hline \multirow{2}{*}{\multicolumn{5}{|c|}{ All first upper molars }} & 2 & 2.70 & 1.76 & 2.74 & 3.44 \\
\hline & & & & & 2 & 2.74 & 1.64 & 1.54 & 3.04 \\
\hline $\begin{array}{l}\text { Mean } \\
\text { Std dev }\end{array}$ & $\begin{array}{l}3.146 \\
0.292\end{array}$ & $\begin{array}{l}2.112 \\
0.134\end{array}$ & $\begin{array}{l}2.532 \\
0.408\end{array}$ & $\begin{array}{l}4.301 \\
0.456\end{array}$ & 2 & 2.60 & 1.76 & 2.00 & 2.84 \\
\hline Minimum* & 2.06 & 1.40 & $\begin{array}{l}0.400 \\
1.64\end{array}$ & 3.30 & 1 & 2.80 & 2.06 & 3.16 & 4.08 \\
\hline \multirow{2}{*}{ Maximum $^{*}$} & 3.52 & 2.30 & 3.22 & $\begin{array}{l}5.50 \\
5.08\end{array}$ & 1 & 2.70 & 1.82 & 2.88 & 3.78 \\
\hline & 3.02 & 2.50 & 3.22 & 5.08 & 1 & 2.78 & 1.84 & 2.12 & 3.26 \\
\hline \multicolumn{5}{|c|}{ First lower M1s retained on $3 \mathrm{~mm}$ sieve } & 1 & 2.76 & 1.88 & 2.14 & 3.22 \\
\hline 3 & 2.82 & 1.64 & 3.06 & 4.10 & 1 & 2.74 & 1.80 & 1.78 & 3.22 \\
\hline 2 & 2.86 & 1.94 & 3.92 & 4.66 & 1 & 2.82 & 1.70 & 2.32 & 3.18 \\
\hline 2 & 2.94 & 1.96 & 3.74 & 4.46 & 1 & 2.68 & 1.72 & 2.10 & 3.16 \\
\hline 2 & 2.90 & 1.88 & 3.44 & 4.26 & 1 & 2.76 & 1.92 & 2.00 & 3.14 \\
\hline 2 & 2.62 & 1.72 & 2.96 & 4.14 & 1 & 2.64 & 1.70 & 2.12 & 3.10 \\
\hline 2 & 2.74 & 1.62 & 3.20 & 4.12 & 1 & 2.80 & 1.84 & 2.08 & 3.08 \\
\hline 2 & 2.70 & 1.78 & 3.24 & 4.06 & 1 & 2.84 & 1.92 & 2.16 & 3.06 \\
\hline 2 & 2.78 & 1.90 & 2.86 & 3.74 & 1 & 2.84 & 1.86 & 1.68 & 3.02 \\
\hline 2 & 2.76 & 1.92 & 1.96 & 3.00 & 1 & 2.62 & 1.70 & 1.92 & 3.00 \\
\hline 1 & 2.94 & 1.84 & 2.88 & 4.04 & 1 & 2.64 & 1.84 & 2.38 & 2.94 \\
\hline Mean $^{*}$ & 2.806 & 1.820 & 3.126 & 4.058 & 1 & 2.62 & 1.78 & 1.86 & 2.92 \\
\hline Std dev ${ }^{*}$ & 0.106 & 0.124 & 0.542 & 0.447 & 1 & 2.62 & 1.70 & 1.74 & 2.88 \\
\hline Minimum ${ }^{*}$ & 2.62 & 1.62 & 1.96 & 3.00 & 1 & 2.64 & 1.80 & 1.88 & 2.72 \\
\hline Maximum $^{*}$ & 2.94 & 1.96 & 3.92 & 4.66 & Mean ${ }^{*}$ & 2.702 & 1.795 & 2.606 & 3.537 \\
\hline \multicolumn{5}{|c|}{ First lower M1s not retained on $3 \mathrm{~mm}$ sieve } & Std dev ${ }^{*}$ & 0.122 & 0.103 & 0.653 & 0.535 \\
\hline 4 & 2.64 & $\begin{array}{l}\text { nea on } \\
1.64\end{array}$ & 3.28 & 4.16 & Minimum $^{*}$ & 2.26 & 1.60 & 1.54 & 2.72 \\
\hline $\begin{array}{l}4 \\
4\end{array}$ & $\begin{array}{l}2.04 \\
2.52\end{array}$ & $\begin{array}{l}1.64 \\
1.68\end{array}$ & $\begin{array}{l}3.28 \\
3.16\end{array}$ & $\begin{array}{l}4.10 \\
3.92\end{array}$ & Maximum ${ }^{*}$ & 2.90 & 2.06 & 3.56 & 4.36 \\
\hline 3 & 2.86 & 1.72 & 3.44 & 4.36 & \multicolumn{5}{|c|}{ All first lower molars } \\
\hline 3 & 2.66 & 1.74 & 3.30 & 4.28 & Mean* & 2.724 & 1.800 & 2.717 & 3.648 \\
\hline 3 & 2.78 & 1.88 & 3.38 & 4.22 & Std dev* & 0.125 & 0.107 & 0.662 & 0.556 \\
\hline 3 & 2.86 & 1.94 & 3.34 & 3.94 & Minimum $^{*}$ & 2.26 & 1.60 & 1.54 & 2.72 \\
\hline 3 & 2.78 & 1.92 & 2.40 & 3.50 & Maximum* & 2.94 & 2.06 & 3.92 & 4.66 \\
\hline
\end{tabular}

TABLE A6. Measurements and age class scores (using the criteria listed in Table A4, above) of isolated first molar teeth of Notomys longicaudatus from Quarry Cave. $\left(^{*}\right)$ Includes broken M1s.

\begin{tabular}{|c|c|c|c|c|c|c|c|c|c|}
\hline $\begin{array}{l}\text { Age } \\
\text { class }\end{array}$ & $\begin{array}{l}\text { Crown } \\
\text { length } \\
(\mathrm{mm})\end{array}$ & $\begin{array}{l}\text { Crown } \\
\text { width } \\
(\mathrm{mm})\end{array}$ & $\begin{array}{l}\text { Height } \\
(\mathrm{mm})\end{array}$ & $\begin{array}{l}\text { Diagonal } \\
\text { length } \\
(\mathrm{mm})\end{array}$ & $\begin{array}{l}\text { Age } \\
\text { class }\end{array}$ & $\begin{array}{l}\text { Crown } \\
\text { length } \\
(\mathrm{mm})\end{array}$ & $\begin{array}{l}\text { Crown } \\
\text { width } \\
\text { (mm) }\end{array}$ & $\begin{array}{l}\text { Height } \\
(\mathrm{mm})\end{array}$ & $\begin{array}{l}\text { Diagonal } \\
\text { length } \\
(\mathrm{mm})\end{array}$ \\
\hline \multicolumn{5}{|c|}{ First upper M1s retained on $3 \mathrm{~mm}$ sieve } & 2 & 3.44 & 2.22 & 3.20 & 5.36 \\
\hline 3 & 3.44 & 2.30 & 3.14 & 5.26 & 2 & 3.22 & 2.30 & 3.32 & 5.36 \\
\hline 3 & 3.42 & 2.38 & 2.94 & 5.18 & 2 & 3.44 & 2.30 & 3.22 & 5.28 \\
\hline 3 & 2.98 & 2.16 & 3.06 & 5.00 & 2 & 3.24 & 2.26 & 3.36 & 5.24 \\
\hline 3 & 3.20 & 2.30 & 2.72 & 4.94 & 2 & 3.24 & 2.28 & 2.92 & 5.22 \\
\hline 3 & 2.42 & 2.32 & 3.06 & 3.36 & 2 & 3.36 & 2.28 & 3.28 & 5.20 \\
\hline 2 & 3.42 & 2.48 & 3.32 & 5.42 & 2 & 3.38 & 2.40 & 3.18 & 5.18 \\
\hline
\end{tabular}




\begin{tabular}{|c|c|c|c|c|c|c|c|c|c|}
\hline $\begin{array}{l}\text { Age } \\
\text { class }\end{array}$ & $\begin{array}{l}\text { Crown } \\
\text { length } \\
(\mathrm{mm})\end{array}$ & $\begin{array}{l}\text { Crown } \\
\text { width } \\
(\mathrm{mm})\end{array}$ & $\begin{array}{l}\text { Height } \\
(\mathrm{mm})\end{array}$ & $\begin{array}{l}\text { Diagonal } \\
\text { length } \\
(\mathrm{mm})\end{array}$ & $\begin{array}{l}\text { Age } \\
\text { class }\end{array}$ & $\begin{array}{l}\text { Crown } \\
\text { length } \\
(\mathrm{mm})\end{array}$ & $\begin{array}{l}\text { Crown } \\
\text { width } \\
\text { (mm) }\end{array}$ & $\begin{array}{l}\text { Height } \\
(\mathrm{mm})\end{array}$ & $\begin{array}{l}\text { Diagonal } \\
\text { length } \\
(\mathrm{mm})\end{array}$ \\
\hline 2 & 3.08 & 2.22 & 3.08 & 5.14 & \multicolumn{5}{|c|}{ All first upper molars } \\
\hline 2 & 3.30 & 2.36 & 3.22 & 5.14 & Mean* & 3.179 & 2.281 & 2.856 & 4.567 \\
\hline 2 & 3.42 & 2.26 & 3.12 & 5.00 & Std dev ${ }^{*}$ & 0.307 & 0.094 & 0.471 & 0.626 \\
\hline 2 & 3.28 & 2.26 & 3.28 & 4.96 & Minimum $^{*}$ & 2.14 & 1.94 & 1.34 & 3.00 \\
\hline 2 & 3.42 & 2.38 & 2.86 & 4.94 & Maximum $^{*}$ & 3.54 & 2.48 & 3.44 & 5.42 \\
\hline 2 & 3.10 & 2.20 & 3.08 & 4.92 & \multicolumn{5}{|c|}{ First lower M1s retained on $3 \mathrm{~mm}$ sieve } \\
\hline 2 & 3.20 & 2.22 & 2.96 & 4.92 & 3 & 3.28 & 2.22 & 3.86 & 4.70 \\
\hline 2 & 3.34 & 2.28 & 3.18 & 4.92 & 2 & 3.22 & 2.12 & 4.12 & 4.94 \\
\hline 2 & 2.18 & 2.46 & 3.28 & 4.88 & 2 & 3.16 & 1.94 & 3.80 & 4.62 \\
\hline 2 & 3.24 & 2.30 & 3.28 & 4.86 & 2 & 3.16 & 2.14 & 3.46 & 4.60 \\
\hline 2 & 3.38 & 2.32 & 3.20 & 4.78 & 2 & 3.14 & 2.12 & 4.06 & 4.56 \\
\hline 2 & 3.08 & 2.20 & 3.00 & 4.78 & 2 & 3.10 & 2.00 & 3.68 & 4.54 \\
\hline 2 & 3.28 & 2.38 & 3.08 & 4.74 & 2 & 3.30 & 1.42 & 3.72 & 4.50 \\
\hline 2 & 3.40 & 2.32 & 3.10 & 4.72 & 2 & 3.20 & 2.16 & 3.86 & 4.48 \\
\hline 2 & 3.54 & 2.30 & 3.00 & 4.70 & 2 & 3.20 & 2.10 & 3.38 & 4.42 \\
\hline 2 & 3.30 & 2.36 & 3.08 & 4.68 & 2 & 2.96 & 2.10 & 3.78 & 4.34 \\
\hline 2 & 3.14 & 2.30 & 3.08 & 4.60 & 2 & 3.16 & 2.02 & 3.64 & 4.32 \\
\hline 2 & 3.48 & 2.40 & 3.44 & 3.90 & 2 & 3.00 & 2.08 & 3.40 & 4.30 \\
\hline 2 & 2.42 & 2.20 & 3.06 & 3.00 & 2 & 2.46 & 1.88 & 3.80 & 4.26 \\
\hline 1 & 3.36 & 2.22 & 2.76 & 4.48 & 2 & 3.06 & 2.22 & 3.54 & 4.24 \\
\hline 1 & 3.28 & 2.18 & 2.90 & 4.46 & 2 & 2.66 & 2.12 & 3.86 & 4.24 \\
\hline 1 & 3.14 & 2.28 & 2.84 & 4.46 & 2 & 3.06 & 1.96 & 3.48 & 4.20 \\
\hline 1 & 3.14 & 2.22 & 3.00 & 4.44 & 2 & 2.50 & 2.08 & 3.84 & 4.14 \\
\hline 1 & 3.44 & 2.34 & 2.92 & 4.42 & 2 & 3.14 & 2.10 & 3.18 & 4.12 \\
\hline 1 & 3.18 & 2.36 & 2.42 & 4.30 & 2 & 2.34 & 2.12 & 2.84 & 3.86 \\
\hline 1 & 2.94 & 2.28 & 2.56 & 4.16 & 2 & 2.38 & 0.88 & 3.44 & 3.86 \\
\hline 1 & 3.36 & 2.44 & 2.62 & 4.10 & 1 & 3.14 & 2.04 & 2.76 & 4.04 \\
\hline 1 & 2.14 & 2.22 & 3.00 & 3.92 & 1 & 2.68 & 2.14 & 3.30 & 4.04 \\
\hline 1 & 3.14 & 2.32 & 2.24 & 3.64 & 1 & 3.06 & 2.04 & 3.12 & 3.98 \\
\hline 1 & 3.28 & 2.30 & 2.28 & 3.62 & 1 & 3.14 & 2.16 & 3.20 & 3.92 \\
\hline 1 & 2.44 & 2.30 & 3.10 & 3.54 & 1 & 3.12 & 2.02 & 2.80 & 3.88 \\
\hline 1 & 3.04 & 1.94 & 1.34 & 3.24 & 1 & 3.18 & 2.10 & 3.14 & 3.84 \\
\hline Mean* & 3.170 & 2.291 & 2.980 & 4.630 & 1 & 3.30 & 2.08 & 2.08 & 3.56 \\
\hline Std $\operatorname{dev}^{*}$ & 0.337 & 0.091 & 0.366 & 0.620 & 1 & 3.20 & 2.06 & 2.68 & 3.48 \\
\hline Minimum* & 2.14 & 1.94 & 1.34 & 3.00 & 1 & 3.12 & 2.10 & 2.30 & 3.32 \\
\hline Maximum* & 3.54 & 2.48 & 3.44 & 5.42 & 1 & 3.10 & 2.04 & 2.10 & 3.30 \\
\hline \multicolumn{5}{|c|}{ First upper M1s not retained on $3 \mathrm{~mm}$ sieve } & 1 & 2.44 & 2.10 & 2.44 & 3.14 \\
\hline 3 & 3.30 & 2.30 & 2.74 & 5.08 & Mean* & 2.999 & 2.021 & 3.312 & 4.121 \\
\hline 2 & 3.02 & 2.32 & 3.12 & 4.88 & Std dev ${ }^{*}$ & 0.293 & 0.254 & 0.568 & 0.437 \\
\hline 2 & 3.14 & 2.28 & 2.74 & 4.84 & Minimum $^{*}$ & 2.34 & 0.88 & 2.08 & 3.14 \\
\hline 2 & 3.16 & 2.12 & 3.06 & 4.76 & Maximum $^{*}$ & 3.30 & 2.22 & 4.12 & 4.94 \\
\hline 2 & 3.34 & 2.24 & 2.28 & 4.76 & \multicolumn{5}{|c|}{ First lower M1s not retained on $3 \mathrm{~mm}$ sieve } \\
\hline 2 & 3.16 & 2.40 & 1.56 & 3.52 & 4 & 3.08 & 2.06 & 3.42 & 4.38 \\
\hline 1 & 3.54 & 2.34 & 3.12 & 4.76 & 3 & 3.06 & 2.02 & 2.56 & 3.86 \\
\hline 1 & 3.42 & 2.38 & 2.86 & 4.76 & 3 & 2.56 & 1.50 & 2.86 & 3.58 \\
\hline 1 & 3.40 & 2.10 & 2.94 & 4.68 & 2 & 3.22 & 2.04 & 4.10 & 4.72 \\
\hline 1 & 3.18 & 2.20 & 2.34 & 4.62 & 2 & 3.14 & 2.18 & 3.98 & 4.60 \\
\hline 1 & 3.10 & 2.16 & 2.30 & 4.04 & 2 & 2.44 & 2.12 & 3.84 & 4.54 \\
\hline 1 & 3.30 & 2.30 & 2.00 & 3.64 & 2 & 3.18 & 2.06 & 3.60 & 4.38 \\
\hline 1 & 3.02 & 2.14 & 1.64 & 3.52 & 2 & 2.64 & 2.20 & 4.04 & 4.38 \\
\hline 1 & 2.80 & 2.18 & 1.74 & 3.26 & 2 & 3.02 & 1.38 & 3.52 & 4.36 \\
\hline Mean $^{*}$ & 3.206 & 2.247 & 2.460 & 4.366 & 2 & 2.58 & 2.18 & 3.92 & 4.26 \\
\hline Std dev* & 0.193 & 0.098 & 0.559 & $\begin{array}{l}0.625 \\
326\end{array}$ & 2 & 3.20 & 2.16 & 3.28 & 4.20 \\
\hline Minimum ${ }^{*}$ & 2.80 & 2.10 & 1.56 & $\begin{array}{l}3.26 \\
5.08\end{array}$ & 2 & 2.96 & 1.98 & 3.66 & 4.20 \\
\hline Maximum ${ }^{*}$ & 3.54 & 2.40 & 3.12 & 5.08 & 2 & 1.96 & 2.20 & 3.74 & 4.20 \\
\hline
\end{tabular}




\begin{tabular}{|c|c|c|c|c|c|c|c|c|c|}
\hline $\begin{array}{l}\text { Age } \\
\text { class }\end{array}$ & $\begin{array}{l}\text { Crown } \\
\text { length } \\
(\mathrm{mm})\end{array}$ & $\begin{array}{l}\text { Crown } \\
\text { width } \\
(\mathrm{mm})\end{array}$ & $\begin{array}{l}\text { Height } \\
(\mathrm{mm})\end{array}$ & $\begin{array}{l}\text { Diagonal } \\
\text { length } \\
(\mathrm{mm})\end{array}$ & $\begin{array}{l}\text { Age } \\
\text { class }\end{array}$ & $\begin{array}{l}\text { Crown } \\
\text { length } \\
(\mathrm{mm})\end{array}$ & $\begin{array}{l}\text { Crown } \\
\text { width } \\
(\mathrm{mm})\end{array}$ & $\begin{array}{l}\text { Height } \\
(\mathrm{mm})\end{array}$ & $\begin{array}{l}\text { Diagonal } \\
\text { length } \\
(\mathrm{mm})\end{array}$ \\
\hline 2 & 2.36 & 1.92 & 3.60 & 4.16 & 1 & 3.04 & 2.14 & 2.24 & 3.54 \\
\hline 2 & 2.44 & 2.02 & 3.60 & 4.14 & 1 & 2.60 & 2.06 & 2.70 & 3.46 \\
\hline 2 & 2.44 & 2.04 & 3.26 & 3.94 & 1 & 3.14 & 2.12 & 2.26 & 3.30 \\
\hline 2 & 3.34 & 1.48 & 1.86 & 3.60 & 1 & 2.86 & 2.06 & 1.68 & 3.08 \\
\hline 2 & 2.68 & 1.52 & 2.50 & 3.30 & 1 & 2.00 & 2.06 & 2.50 & 3.06 \\
\hline 2 & 2.44 & 2.10 & 2.00 & 2.98 & 1 & 2.32 & 2.16 & 2.12 & 2.60 \\
\hline 1 & 3.08 & 1.88 & 3.44 & 4.28 & Mean* & 2.812 & 1.994 & 3.075 & 3.890 \\
\hline 1 & 3.20 & 2.14 & 3.46 & 4.18 & Std dev ${ }^{*}$ & 0.378 & 0.213 & 0.665 & 0.509 \\
\hline 1 & 3.10 & 1.86 & 2.90 & 4.10 & Minimum $^{*}$ & 1.96 & 1.38 & 1.68 & 2.60 \\
\hline 1 & 3.12 & 2.14 & 3.00 & 4.06 & Maximum & 3.34 & 2.20 & 4.10 & 4.72 \\
\hline 1 & 2.60 & 2.06 & 3.22 & 3.88 & \multicolumn{5}{|c|}{ All first lower molars } \\
\hline 1 & 3.16 & 1.98 & 2.68 & 3.80 & $\begin{array}{l}\text { All first lowe } \\
\text { Mean* }^{*}\end{array}$ & 2.901 & 2.007 & 3.188 & 4.000 \\
\hline 1 & 2.40 & 2.02 & 3.12 & 3.78 & Std dev ${ }^{*}$ & 0.350 & 0.232 & 0.627 & 0.487 \\
\hline 1 & 3.18 & 1.92 & 2.88 & 3.72 & Minimum ${ }^{*}$ & 2.34 & 0.88 & 1.68 & 2.60 \\
\hline 1 & 3.06 & 2.02 & 3.02 & 3.64 & Maximum* & 3.34 & 2.22 & 4.12 & 4.94 \\
\hline
\end{tabular}

TABLE A7. Raw numbers of murid specimens (left and right jaws combined) from Caladenia Cave, retained or not retained on a $3 \mathrm{~mm}$ sieve in each of five categories of completeness, ranging from complete jaws with all molars present (1) to isolated first molars (5) (details in Table A1 above). Species are listed from smallest at the beginning to largest at the end.

\begin{tabular}{llllllr} 
& 1 & 2 & 3 & 4 & 5 & Totals \\
\hline $\begin{array}{l}\text { Pseudomys albocinereus } \\
\text { Retained on } 3 \text { mm sieve }\end{array}$ & & & & & & \\
$\begin{array}{l}\text { Upper and lower combined } \\
\text { Not retained on } 3 \text { mm sieve }\end{array}$ & 10 & 6 & 12 & 14 & 2 & 44 \\
Upper and lower combined & 5 & 0 & 4 & 17 & 160 & 186 \\
Species total & & & & & & $\mathbf{2 3 0}$ \\
& & & & & & \\
$\begin{array}{l}\text { Pseudomys occidentalis } \\
\text { Retained on } 3 \text { mm sieve }\end{array}$ & & & & & & \\
Upper and lower combined & 2 & 2 & 4 & 1 & 0 & 9 \\
$\begin{array}{l}\text { Not retained on } 3 \text { mm sieve } \\
\text { Upper and lower combined }\end{array}$ & 0 & 0 & 0 & 0 & 37 & 37 \\
Species total & & & & & & $\mathbf{4 6}$
\end{tabular}

\section{Pseudomys fieldi}

Retained on $3 \mathrm{~mm}$ sieve

Upper and lower combined

Not retained on $3 \mathrm{~mm}$ sieve

Upper and lower combined $\quad 0 \quad 0 \quad 0 \quad 0 \quad 1 \quad 1 \quad r r$

Species total

Notomys sp. indet.

Retained on $3 \mathrm{~mm}$ sieve

Upper and lower combined

Not retained on $3 \mathrm{~mm}$ sieve

Upper and lower combined

Species total $\begin{array}{llllll}1 & 2 & 3 & 4 & 5 & \text { Totals }\end{array}$

\section{Pseudomys shortridgei}

Retained on $3 \mathrm{~mm}$ sieve

Upper and lower combined $\quad \begin{array}{lllllll}0 & 0 & 2 & 0 & 0 & 2\end{array}$

Not retained on $3 \mathrm{~mm}$ sieve

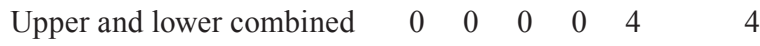

Species total

\section{Rattus fuscipes}

Retained on $3 \mathrm{~mm}$ sieve

Upper and lower combined $\quad \begin{array}{lllllll}0 & 0 & 0 & 0 & 0 & & 0\end{array}$

Not retained on $3 \mathrm{~mm}$ sieve

Upper and lower combined $\quad \begin{array}{llllll}0 & 0 & 0 & 1 & 2 & 3\end{array}$

Species total

\section{Rattus tunneyi}

Retained on $3 \mathrm{~mm}$ sieve

Upper and lower combined $\quad \begin{array}{llllll}0 & 0 & 0 & 0 & 0 & 0\end{array}$

Not retained on $3 \mathrm{~mm}$ sieve

Upper and lower combined $\quad 0 \quad 0 \quad 0 \quad 0 \quad 0011$

Species total

6

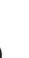

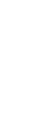

